\title{
ANTONIO TRUEBA ANTE LA REVOLUCIÓN DE 1868 Y LA ABOLICIÓN FORAL: EN EL TRÁNSITO DESDE LA LITERATURA DEL DOBLE PATRIOTISMO A LA NACIONALIDAD VASCA
}

\section{ANTONIO TRUEBA BEHIND THE REVOLUTION OF 1868 AND THE ABOLITION OF THE FORAL LAW: ON THE ROAD FROM THE LITERATURE OF DOUBLE PATRIOTISM TO BASQUE NATIONALITY}

\author{
Javier Pérez Núñez \\ Universidad Autónoma de Madrid
}

\begin{abstract}
SUMARIO: I INTRODUCCIÓN.- II. PUNTO DE PARTIDA: EL UNIVERSO CATÓLICO-FUERISTA DE ANTONIO TRUEBA.- III. ANTE LA REVOLUCIÓN DE 1868: EL APOCALIPSIS DONOSIANO.- IV. ANTE LA ABOLICIÓN FORAL: LA RUPTURA CON LA MONARQUÍA.- V. CONCLUSIONES
\end{abstract}

Resumen: El artículo realiza un estudio histórico de la literaria costumbrista del archivero y cronista de Vizcaya Antonio Trueba durante el sexenio democrático de 1868 y los primeros años de la Restauración, en los que se produjo la abolición de los regimenes forales vascongados. Observada la primera experiencia desde un conservadurismo y catolicismo bastante extremo, lo sitúo en la linde con el carlismo en armas, que no llegó a profesar por su rechazo de la violencia y fidelidad a la Monarquía isabelina y, por ende, a la de la Restauración. Contemplada la abolición foral desde un fuerismo muy idealista, le provocó la ruptura con ambas Monarquías y un alejamiento de doble patriotismo a través de un proceso de nacionalización negativa española y de afirmación de la idea de nacionalidad vasca.

\begin{abstract}
This article carries out a historical study of the folk literature written by Vizcaya archivist and chronicler Antonio Trueba during the democratic sixyear period of 1868 and the first years of the Restoration, in which the abolition of the Basque regional regimes took place. Observing the first experience from a fairly extreme conservatism and catholicism, he stood at the edge with the carlism in arms, which he failed to profess for his rejection of violence and fidelity to the Elizabethan Monarchy and, therefore, to that of the Restoration. Considering the abolition of the foral law from a very idealistic fuerismo caused him to break with them and a departure from double patriotism through a process of negative Spanish nationalization and affirmation of the idea of the Basque nationality.
\end{abstract}

Palabras clave: Revolución democrática de 1868, Fueros Vascos, Carlismo, Conservadurismo, Literatura costumbrista.

Keywords: Democratic Revolution of 1868, Basque Fueros, Carlism, Conservatism, Folk literature 


\section{I.- INTRODUCCIÓN.}

En dos ocasiones anteriores ya hemos abordado el estudio histórico de la obra literaria de Antonio de Trueba Quintana (1819-1889), escritor, periodista, archivero y cronista de la provincia de Vizcaya. En este tercer trabajo ${ }^{1}$ lo que nos proponemos es afrontar el gran shock que a él y a sus correligionarios fueristas conservadores les produjo, primero, el sexenio que arrancó con la revolución gloriosa de 1868 y, después, la abolición de los regímenes forales vascongados, que acompañó al recién estrenado régimen de la restauración. Si en aquellos estudios comenzamos señalando que el escritor vizcaíno disponía desde 1895 de una estatua erigida en su homenaje en la plaza Jardines de Albia de Bilbao ${ }^{2}$, en éste debemos agregar que enfrente, a escasos cincuenta metros debajo del Palacio de Justicia, desde 2003 cuenta con otra Sabino de Arana Goiri. Están muy cercanos el padre del nacionalismo vasco y Antonio Trueba porque, durante el tiempo que trata este artículo y siendo éste uno de los mentores, comienza a producirse el tránsito del fuerismo, al menos en el sector intransigente, al nacionalismo de aquél, del doble patriotismo español y vasco al dominio exclusivo de éste.

Así el nacionalismo vasco lo acogió y, con ocasión del centenario de su nacimiento, la prestigiosa revista Hermes le dedicó en 1920 un número monográfico. Entonces, como recordaba uno de los autores de la publicación, Carmelo Echegaray, Antonio Trueba no era más que un recuerdo grato de la infancia, el de los cuentos que les habian leído las madres o los maestros en la escuela ${ }^{3}$. Así era porque fue en los años centrales de la Monarquía isabelina, los cincuenta y los sesenta del ochocientos, cuando el escritor vizcaíno adquirió cierto renombre y reconocimiento como literato. De esta manera, siguiendo el modelo y haciéndose un hueco en la senda abierta por la hispano-alemana Cecilia Böhl de Faber (Fernán Caballero), sus obras, principalmente los poemas y cuentos, estuvieron en las estanterias de muchas bibliotecas, en la del Palacio Real -era uno de los autores preferidos de la reina, "el bardo querido de Isabel II"y en las de las clases acomodadas y, también, en las de las más humildes, convirtiéndose en una lectura típica familiar. Por tanto, alcanzó una gran popularidad y, por eso, muchos de sus títulos fueron publicados en distintos periódicos y revistas, algunos de sus libros fueron reeditados con el patrocinio

\footnotetext{
1 Como los anteriores, este trabajo se enmarca en el proyecto de investigación "Intercambios culturales y creación de identidades a través de la literatura, ss. XIX y XX” (HAR2016-76398-P). Los precedentes son: "Didáctica para una nación católico-conservadora: los cuentos populares de Antonio Trueba", presentado al Congreso "La nación omnipresente: nuevos enfoques sobre los procesos de nacionalización en la España contemporánea”. Museo do Pobo Galego y Facultade de Xeografia e Historia (USC). Santiago de Compostela, 6-7 de septiembre de 2018; y "La comunidad imaginada por Antonio Trueba: ¿el paraíso foral vasco durante la Monarquia isabelina?”, en Carmen de la Guardia Herrero, Florencia Peyrou Tubert y Pilar Toboso Sánchez (edit.), Escribir identidades. Diálogos entre la Historia y la Literatura, Sintesis. Madrid, 2020, pp. 47-73.

2 Eva Diez Paton, "La villa de Bilbao a la memoria de Antonio de Trueba: Actos conmemorativos y elementos para el recuerdo", Bidebarrieta, n 25, 2014, pp. 96-99 y Maite Paliza Mondaute, "El monumento al poeta Antonio Trueba, obra de Mariano Benlliure y su influencia en la escultura conmemorativa vizcaina del siglo XX", Ondare. Cuadernos de artes plásticas y monumentales, $\mathrm{n}^{\circ}$ 23, 2004, pp.438-445.

3 Carmelo Echegaray, "Lo que significa para nosotros el nombre de Trueba", Hermes, $n^{\circ} 57$, 1920, p. 169.
} 
real, así como traducidos a varios idiomas y leídos con fervor al otro lado del Atlántico, al menos por los emigrados vascos ${ }^{4}$.

Además, cuando declinaba su figura como literato, Antonio Trueba consiguió prolongar su celebridad gracias a su labor como cronista de Vizcaya. Así, su Bosquejo de la organización social de Vizcaya-obra encargada por la Diputación de esta provincia con ocasión del debate en el Senado en 1864 sobre la singularidad vascongada y que presentaba a la comunidad foral vizcaina como un modelo de organización social- tuvo una gran repercusión, sobre todo, después de recibir una mención honorífica en la exposición universal de París de 1867 . De esta manera, al margen de la importante influencia que posteriormente tendría en la impronta ruralista de la cultura del primer nacionalismo vasco, en ese momento la notoriedad conseguida sirvió para dar un nuevo impulso a su carrera literaria. Por eso, durante el sexenio y primeros años de la restauración, siguió publicando obras de ficción y logró mantener cierta fama. La suficiente como para que en 1873 los editores de la revista La Ilustración española y americana regalaran a sus suscriptores por las fiestas navideñas un ejemplar del último libro del narrador vizcaíno El gabán y la chaqueta ${ }^{5}$ y también como para que la acreditada publicación gala Revue des Deux Mondes en enero de 1876 le dedicara un artículo, "Un conteur espagnol contemporain - Antonio de Trueba".

Este estudio de Lucien Louis-Lande ${ }^{6}$, como el introductorio del monográfico de la revista Hermes, coinciden en caracterizar al escritor vizcaíno no por lo elevado de su pensamiento ni por la grandeza de sus concepciones, sino por su corazón sensible e ingenuidad encantadora, por su lenguaje sencillo y llano, y por su cercanía y familiaridad 7 . Y es que es aquí donde reside nuestro interés histórico por la obra literaria de Antonio Trueba. En su capacidad para saber captar a un gran número de lectores a través de un lenguaje muy peculiar que, creado por el autor, quiere hacer pasar como popular. Por medio de unos relatos inspirados y desarrollados, prioritariamente, en el País Vasco, sobre todo en Las Encartaciones vizcaínas -en cuyo concejo de Galdames nació el 24 de diciembre de $1819 \mathrm{y}$ en el cercano de Sopuerta vivió durante su infancia-, y, ocasionalmente, en Madrid, la tierra que le acogió. Mediante unas narraciones escenificadas en un entorno aldeano y un paisaje rural sumamente idealizado y articuladas en unas tramas que, privilegiando los aspectos costumbristas,

4 Montserrat Amores Garcia, "Antonio de Trueba y su obra literaria” en Javier Barrio Marro et al, Antonio de Trueba (1819-1889). Cronista de Bizkaia / Antonio de Trueba (1819-1889). Bizkaiko kronista, Museo de Las Encartaciones/ Juntas Generales de Bizkaia, Bilbao, 2020, pp. 143-146; y Gregorio Múgica, Trueba: su significación en la moderna literatura vasca, Imprenta Martín, Mena y $\mathrm{C}^{\mathrm{a}}$, San Sebastián, 1914, pp. 51-55.

5 El Correo Vascongado, 26-04-1873. Para la perduración de la fama de Antonio Trueba, Fernando Molina Aparicio, La tierra del martirio español. El País Vasco y España en el siglo del nacionalismo, Centro de Estudios Políticos y Constitucionales, Madrid, 2005, pp. 244-245.

6 Viajero francés, autor de Basques et navarrais. Souvenirs d'un voyage dans le nord de l'Espagne, Librairie acadèmique Didier, París, 1878.

7 Lucien Louis-Lande, "Un conteur espagnol contemporain - Antonio de Trueba" Revue des Deux Mondes, $\mathrm{n}^{\circ} 13,1876$, pp. 410-432. Citado del texto traducido y anotado por Antonio Trueba, y recogido como apéndice en Cuentos del hogar, $2^{\mathrm{a}}$ edición corregida y aumentada, Imprenta y Librería de Miguel Gijarro, Madrid, 1876, p. 359; y Hermes. Revista del País Vasco, nº 57, 1920, Homenaje a Trueba, pp.167-168. 
folklóricos y tradicionales populares, cuentan con unos argumentos y personajes planos, simples y pueriles. En fin, un público muy nutrido se vio atraído y aleccionado por una literatura como la de Antonio Trueba, siempre orientada por una moral católica ortodoxa y una ideología muy conservadora y fuerista recalcitrante ${ }^{8}$.

Para la construcción cultural de las identidades nacionales y de la multiplicidad de identidades subnacionales que conviven con ellas la literatura de ficción resulta primordial. Así lo piensa Benedict Anderson, autor de la célebre definición de la nación como comunidad imaginada, que seguimos en este artículo, ya que, gracias a ella, sitúan a ésta en un espacio y un tiempo determinados, y hacen sentir a los individuos como sujetos y, por lo tanto, como miembros de la misma. De esta manera, para este gran estudioso del nacionalismo, las novelas (que hacemos extensivas a los cuentos) constituyen un instrumento fundamental de nacionalización, ya que, a partir de la simultaneidad de acontecimientos y situaciones, de coincidencias temporales, de sucesión de plurales (lugares, espacios), de revelación de certezas interconectadas, etc., permiten a los individuos considerarse partícipes de una comunidad con la que comparten determinados rasgos ${ }^{9}$. Este proceso de nacionalización es más intenso si se establece un vínculo de cercanía, familiar, entre los individuos y el autor de la obra literaria. Esto es lo que ocurre con Antonio Trueba, que viene a representar el papel del abuelo, del cura o maestro del pueblo.

Por eso el estudio histórico de su obra literaria adquiere una especial importancia. También lo tiene porque, como subraya Lucien Louis-Lande, en sus libros realiza muchas digresiones, que utiliza para "describir el país vascongado y encomiar a sus habitantes recordando su grandeza pasada y lamentando sus males presentes"10. Pues bien, además, estas reflexiones de carácter político y cultural son particularmente valiosas porque se retoman en alguno de sus artículos periodísticos (principalmente, como veremos, de El Correo Vascongado, El Noticiero Bilbaíno y La Paz) y en su labor como cronista, sobre todo, cuando en 1876, en el proceso de remodelación de los regimenes forales, las Diputaciones vascongadas le encargan la elaboración de los principales recursos colectivos.

\footnotetext{
8 Montserrat Amores García, Antonio de Trueba y el cuento popular, Departamento de Cultura de la Diputación Foral de Bizkaia, Bilbao, 1999, pp. 50-51, 85-86 y 104-105; Andrés GonzálezBlanco, Antonio de Trueba: su vida y sus obras (páginas escogidas), Librería de Villar, Bilbao, 1914, pp. 11-13; Jon Juaristi, El linaje de Aitor. La invención de la tradición vasca, Taurus, Madrid, 1987, pp. 137-138 y 141-142; y Antonio Trueba, Narraciones populares, A. Jubera editor, Madrid, 1874, pp. VII-X.

9 Benedict Anderson, Comunidades imaginadas. Reflexiones sobre el origen y la difusión del nacionalismo, Fondo de Cultura Económica, México, 1993, principalmente, pp. 22-76. Compartimos la interpretación de la definición de nación como comunidad imaginada realizadas por Justo Beramendi y Antonio Rivera, Antonio, "La nacionalización española: cuestiones de teoría y método", Félix Luengo Teixidor y Fernando Molina Aparicio (edit.), Los caminos de la nación. Factores de nacionalización en la España contemporánea, Comares, Granada, 2016, pp. 4 y 7-8, y seguimos las reflexiones sobre las relaciones con la literatura realizadas por Xavier Andreu Miralles, El descubrimiento de España. Mito romántico e identidad nacional, Taurus, Barcelona, 2016, pp. 15-19.
}

10 Lucien Louis-Lande, “Un conteur espagnol..., op. cit, pp. 398-399. 
Con estas reflexiones Antonio Trueba construyó un discurso, que partía asumiendo la doble identidad compartida o doble patriotismo, español y vasco, característico del fuerismo de la época isabelina ${ }^{11}$. Pues bien, relajado al final del reinado, desde la visión apocaliptica de la revolución de 1868 volvió a ser recuperado como ideal. Pero, paralelamente, al lograr mantenerse al margen el País Vasco, empezó a desarrollar un relato de diferenciación, asentado en la incapacidad de las demás provincias para impedir el dominio del desorden moral y material, que para él era la expresión de aquella. La narración mantiene la misma linea argumental con la guerra carlista porque, aunque nuestro autor la rechazara y fijara su alternativa en la restauración canovista, le parecía incomparablemente más admisible que los distintos desarrollos ocasionados por la Gloriosa y la consideraba exclusivamente su consecuencia. De esta manera, indicado el carlismo a recuperar, aunque fuera por medios que no compartía, los grandes principios conservadores que profesaba y también para él la recién inaugurada Monarquía alfonsina, le resultaba incompresible que se considerara a los Fueros los causantes del conflicto civil y que a su terminación se planteara su abolición. Por eso, fue en torno a este momento cuando el discurso comenzó a ser dominado por una suerte de "desnacionalización española"12 que, con su ruptura con la monarquía, acabó derivando en un cambio radical del doble patriotismo hacia la idea de nacionalidad como identidad colectiva de los vascos.

\section{II.- PUNTO DE PARTIDA: EL UNIVERSO CATÓlICO-FUERISTA DE ANTONIO TRUEBA.}

El nombramiento en 1862 como archivero y cronista de Vizcaya supuso una cesura en la trayectoria vital y profesional de Antonio Trueba. Entonces se cerró una etapa, abierta a los 16 años cuando, para evitar ser reclutado durante la primera guerra carlista, migró de Las Encartaciones a Madrid. Aquí, donde fue acogido por un familiar, se inició la carrera para intentar dedicarse a la actividad literaria. Así, contando con un bagaje cultural muy básico, pero con la gran afición que desde chaval tenía por los romances de ciego, las coplas y los cuentos, primero, se formó de manera autodidacta a través de las impresiones que le causaron las transformaciones liberales durante el tiempo de las Regencias de María Cristina y Espartero, y las lecturas de los principales autores románticos del momento. Seguidamente, ya durante el reinado efectivo de Isabel II y el dominio de los moderados, se labró un círculo de amistades literarias, que le acabó abriendo el mundo editorial para sus primeras y fallidas incursiones en la novela histórica, pero, sobre todo, para sus colaboraciones periodísticas en diarios de signo conservador, como La España, La Esperanza o La Época, y aportaciones literarias en la Revista Vascongada o el Semanario Pintoresco Español, donde empezó a publicar sus cuentos. Consagrado ya como escritor, con el éxito alcanzado en 1851 con El libro de los cantares, logró un puesto de redactor en La Correspondencia de España, que le permitió dedicarse plenamente a la literatura. A partir de entonces aparecieron sus recopilaciones de cuentos

11 Una primera aproximación al concepto de doble patriotismo en Fernando Molina Aparicio, La tierra del martirio...op. cit., p. 44.

12 Así definimos a la recepción de la nacionalización negativa que conceptualiza Alejandro Quiroga en "La nacionalización de España. Una propuesta teórica”, Ayer, 90 (2013), pp. 32-33. 
más conocidas: Cuentos de color de rosa (1859), Cuentos campesinos (1860), Cuentos populares (1862) y, posteriormente, Cuentos de vivos y muertos, contados por el pueblo (1866) y Cuentos de varios colores (1866) ${ }^{13}$.

Según confesara el propio Antonio Trueba, si El libro de los cantares y sus posteriores trabajos poéticos se vieron influidos por la lectura de Lo Gayter de Llobregat de Joaquín Rubio Ors, sus narraciones cortas lo fueron por la de la obra de Cecilia Böhl de Faber ${ }^{14}$. Así, como gran conocedor y admirador de su literatura -la invocó como oráculo y referenció como paradigma en varios de sus cuentos, considerándola como la "gran fotógrafa de costumbres"-, el escritor vizcaíno, en la misma búsqueda romántica del espíritu o carácter nacional, lo que hizo fue reemplazar el escenario del campo andaluz utilizado por aquella por, principalmente, el rural vasco (sobre todo, el de su comarca natal vizcaína) y, secundariamente, el madrileño. A partir de aquí siguió las pautas literarias e ideológicas reaccionarias y tradicionalistas de Fernán Caballero, asumiendo su lenguaje popular, que suponía corregir "la falta de sintaxis y la falta de decencia", y rechazando los folletines y la novela social porque -advertía- "con la hipocresía populachera" daban pábulo a una moral en la que "de Dios, de la sociedad, de la familia y de la propiedad no quedaba ni rastro". De esta manera, sus narraciones de carácter costumbrista eran exactamente lo contrario, la defensa y difusión de los principios y valores del catolicismo ortodoxo conservador. Identificados estos parámetros confesionales con el ser nacional, era en el mundo rural donde se revelaban en toda su pureza, encarnando la verdadera religiosidad, la familia tradicional patriarcal, la sumisión a las jerarquías heredadas y al orden social establecido, la fidelidad a las costumbres y tradiciones, la naturalidad, austeridad, sencillez y conformismo. Estos rasgos para Antonio Trueba se sublimaban en el País Vasco, donde, gracias al mantenimiento de los regímenes forales, hacian de él un lugar ejemplar, una arcadia feliz; eso sí, bajo esa perspectiva ideológico-religiosa ${ }^{15}$.

De esta manera, al tiempo que se vincula al entorno monárquico autoritario y neocatólico del conservadurismo y con Fernán Caballero colabora en el desenvolvimiento de la primera versión del nacional-catolicismo ${ }^{16}$, el narrador vizcaíno formó parte de la generación isabelina del fuerismo literario,

13 Montserrat Amores García, Antonio de Trueba...op. cit., pp.17-19 y 24-25; Ricardo Becerro de Bengoa, Trueba. Estudio biográfico, La España Moderna, Madrid, 1892, pp. 17-19 y 20-21; José Antonio Ereño Altuna, Antonio de Trueba: literatura-historia-politica (con la disculpa de unos artículos de Trueba), J.A. Ereño, Bilbao, 1998, pp. 29 y 82; y Lucien Louis-Lande, "Un conteur espagnol...op. cit, pp. 323-328.

14 Antonio Trueba, "Notas autobiográficas” en La Ilustración española y americana, n IV, 1889, p. 62 .

15 Montserrat Amores García, Antonio de Trueba...op. cit., pp.53-54 y 172-175; Xavier Andreu Miralles, El descubrimiento de España...op. cit., pp. 210 y 320-327; Jon Juaristi, El linaje de Aitor...op. cit., p. 26; Gregorio Múgica, Trueba: su significación...op. cit., pp. 44 y 50; Antonio Trueba, Historia de dos almas, una blanca y una negra, A. de Carlos e hijo editores, Madrid, 1876, p. 42; e Iris M. Zavala, "La literatura: romanticismo y costumbrismo", Hans Juretschke (coord.), La época del romanticismo (1808-1874), José María Jover Zamora (dir.), Historia de España Menéndez Pidal, Espasa Calpe, Madrid, 1989, t. 35, v. 2. Las letras, las artes, la vida cotidiana, pp.123-125.

16 Javier Pérez Núñez, "Didáctica para una nación católico-conservadora...op.cit., pp. 13-22. 
contribuyendo a la construcción cultural de la tradición vasca. Lo hizo sobre todo durante la segunda etapa de su vida, la abierta a finales de 1862 cuando se trasladó a Vizcaya a ocupar el cargo de archivero y cronista de la provincia ${ }^{17}$. Así, aunque al igual que en la anterior etapa -como ya hemos reseñado- continuara escribiendo narraciones cortas, se sumó a la labor de la invención de la tradición vasca mediante la difusión de los grandes mitos fueristas y de la imagen idílica de universo rural vasco. A la primera, es decir, a la divulgación de los principales presupuestos en los que se querian sustentar los regimenes forales como la independencia originaria, monoteísmo primitivo, la incorporación pactada a la Corona de Castilla, el igualitarismo y el disfrute ancestral de las libertades, la pureza de sangre e hidalguía universal18, contribuyó con la Defensa de un muerto atacado por el Excmo. Sr. D. Manuel Sánchez Silva (1865); trabajo realizado para hacer frente a las criticas vertidas contra los regimenes forales vascongados por este senador andaluz en 1864, primero, en La Soberanía Nacional con cinco artículos recogidos bajo el título "Unidad Constitucional" y, después, en la cámara alta, que provocaron un intenso debate. Y también participó con La paloma y los halcones (1865), revisión de una novela histórica anterior que seguia las pautas de la narración dedicada al considerado primer señor de Vizcaya, Jaun Zuría. A la segunda, a la afirmación de la impronta ruralista, contribuyó marginalmente, con el variopinto Capitulos de un libro sentidos y pensados viajando por las provincias Vascongadas (1864) y, principalmente, con El libro de las montañas (1867), canto apasionado a un idílico y mítico País Vasco acompañado de un apéndice que contiene una lectura muy fuerista de la historia y de la ordenación de los regímenes forales, y, sobre todo, con el ya destacado Bosquejo de la organización social de Vizcaya (1867), memoria indicada a afianzar la comunidad foral vizcaína ante la Corona, que fue presentada a la exposición universal de París de este año, recibiendo una mención honorífica ${ }^{19}$. Esta obra, que tuvo una gran repercusión e influencia notoria posterior, muestra una estructura social modélica producto para el escritor vizcaíno de la conjunción de un pueblo virtuoso, como el vasco, y de una constitución ancestral idónea e intangible a la mudanza de los tiempos, como eran los Fueros. De ella Antonio Trueba hace proceder la organización agraria del caserío que, estrechamente vinculada a la institución también nuclear de la familia de carácter patriarcal, la perpetúa en el tiempo gracias a la sucesión troncal foral. Los distintos caseríos familiares, agrupados en aldeas formadas en torno a parroquias, configuran para el narrador vizcaíno una especie de comunidad que suple las carencias de

17 Para su nombramiento y labor como archivero y cronista de Vizcaya Joseba Agirreazkuenaga, "Patriotismo foral y gobierno de Bizkaia en tiempos de Antonio de Trueba" en Javier Barrio Marro et al, Antonio de Trueba (1819-1889). Cronista de Bizkaia / Antonio de Trueba (1819-1889). Bizkaiko kronista, Museo de Las Encartaciones/ Juntas Generales de Bizkaia, Bilbao, 2020, pp. 304-316.

18 José Luis Granja, Justo Beramendi y Pere Anguera, La España de los nacionalismos y las autonomías, Ed. Síntesis, Madrid, 2003, pp. 35-37; Jon Juaristi, El linaje de Aitor...op. cit., p. 107167; y Coro Rubio Pobes, La identidad vasca en el siglo XIX. Discurso y agentes sociales, Biblioteca Nueva, Madrid, 2003, pp..132-145 y 310-325.

19 José Antonio Ereño Altuna, Antonio de Trueba...op. cit., pp. 37-40; Andrés González-Blanco, Antonio de Trueba...op. cit., pp. 14-17; y Mikel Urquijo Goitia, Dos aproximaciones a la sociedad vasca del ochocientos, Servicio Editorial de la Universidad del País Vasco, Bilbao, 2000, pp. 12 y 28. 
aquellos, los complementa y les facilita un desarrollo social armónico y un alto grado de bienestar ${ }^{20}$.

Tanto este libro sintetizado como el anterior se enmarcan en la basculación al fuerismo tradicionalista que se genera en las instituciones provinciales vizcaínas y en las otras vascas. Pues bien, Antonio Trueba, que siempre había estado alineado con el neocatolicismo, otorgando primacía a la religión católica y teniendo a la triada de "Dios, la patria y la familia" como principales divisas de su obra literaria, no pudo por menos de participar en esa inclinación, en el rearme foral en clave católica, como demostró su colaboración en el Semanario Católico Vasco-Navarro. Así, coincidiendo la promulgación de los preceptos reaccionarios del Papa Pio IX, condenando el progreso y la modernidad en su conjunto, con el debate en el Senado sobre la singularidad vasca, se produjo la articulación del foral-catolicismo. Condensado en el lema Jaungoikoa eta Foruak, contemplaba el País Vasco foral, en cuanto a lugar más cercano a la tradición, como la vanguardia del catolicismo, como una especie de oasis contrarrevolucionario y, por ello, el mejor escudo protector contra las "perniciosas innovaciones foráneas". Esto no ponía en cuestión el doble patriotismo, español y vasco, que había imperado en el fuerismo durante la Monarquía isabelina, pero sí una afirmación del segundo, igualándose con el provincial hasta entonces más fuerte, y un decaimiento del primero y de la adhesión a la reina por la deriva liberal o no católica ortodoxa de las instituciones centrales ${ }^{21}$. Esta evolución también la tuvo el escritor vizcaíno, con la salvedad de la relación con Isabel II, a la que profesó una estrecha fidelidad no sólo cuando en 1865 la acompañó en el viaje realizado a las Vascongadas ${ }^{22}$, sino después de su destronamiento.

\section{III.- ANTE LA REVOLUCIÓN DE 1868: EL APOCALIPSIS DONOSIANO.}

Por lo tanto, al arranque de la Gloriosa en septiembre de 1868 gran parte de la obra como las principales relaciones de Antonio Trueba se encontraban insertas en la órbita del fuerismo tradicionalista, dominante en Vizcaya y en gran parte del País Vasco. De esta manera, resulta bastante lógico que compartiera con esa corriente de opinión la visión apocaliptica donosiana sobre la revolución democrática y laica desplegada a partir de entonces, y también la actuación inmediata llevada a cabo por el grupo dirigente. Así, éste, al lograr mantenerse en el poder con el cambio, pudo, primero, construir una especie de cordón sanitario para preservar al país del contagio revolucionario y, segundo, contribuir con su

20 Javier Pérez Núñez, "La comunidad imaginada por Antonio Trueba...op. cit., pp. 56-60.

21 Joseba Agirreazkuenaga, "Patriotismo foral y gobierno de Bizkaia...op. cit., pp. $270-271$ y 284; María Cruz Mina Apat, "Historia y politica: las vicisitudes de una ley" en Joseba Agirreazkuenaga y José Ramón Urquijo Goitia, (edit.), 150 años del Convenio de Bergara y la ley de 25-X-1839, Parlamento Vasco, Vitoria-Gasteiz,1990, pp. 284-292; Javier Pérez Núñez, La Diputación Foral de Vizcaya. El régimen foral en la construcción del Estado liberal (1808-1968), Centro de Estudios Constitucionales/Universidad Autónoma de Madrid, Madrid, 1996, pp. 589592 y 601-604; José María Portillo Valdés, El sueño criollo. La formación del doble constitucionalismo en el País Vasco y Navarra, Nerea, Donostia-San Sebastián, 2006. pp. 170-176; y Coro Rubio Pobes, La identidad vasca en el siglo XIX...op. cit., pp. 124-125 y 450-458.

22 En Mari-Santa, cuadros de un hogar y sus contornos, 1874, pp. 198-200, Antonio Trueba narra el viaje que realizó la reina a estas provincias, señalando que dejó en ellas "grata memoria de su piedad y caridad inagotable", así como de "esperanza y consuelos verdaderamente maternales". 
influencia moral a que la representación por las provincias vascas en las Cortes constituyentes fuera cubierta por los candidatos de la amalgama católicotradicionalista. Aunque se consiguiera, conformaron una minoria que apenas influyó en un sentido retrógrado en la futura Carta magna y, sobre todo, nada pudo hacer por mantener la intolerancia religiosa y la exclusividad católica de la Monarquía isabelina. Así las cosas, las Diputaciones forales no asistieron al acto de promulgación de la nueva Constitución de 5 de junio de 1869, que alumbraba una Monarquía parlamentaria en un Estado liberal-democrático ${ }^{23}$.

El escritor vizcaíno también disentía de este nuevo modelo político, pero entonces su alternativa se seguía situando en la arrumbada Monarquía constitucional doctrinaria de Isabel II. Así, aunque coincidiera en muchos de sus presupuestos ideológicos, en su horizonte mental no se encontraba ni la Monarquía tradicional carlista ni la vía de la sublevación armada para alcanzarla ${ }^{24}$, como auspiciaba gran parte de la clase dirigente vizcaína. Por eso no tomó parte en la frustrada insurrección carlista de agosto de 1870, en la que se vio involucrada la Diputación vizcaína a la que estaba adscrito. A pesar de ello, de la misma manera que ocurrió con los miembros de esta corporación y algunos de sus empleados, él también fue destituido del cargo de archivero, manteniendo el de cronista. Antonio Trueba achacaría este cese a las intrigas de "media docena de seudo-liberales" y es que la verdad estaba en el punto de mira de ciertos sectores por sus afinidades con prohombres tradicionalistas y su colaboración en el periódico oficioso carlista Euscalduna, que le supuso la apertura de un proceso por la publicación de un artículo en el que se vertian críticas a la administración de la Diputación guipuzcoana de signo liberal. Con todo, permaneció en Bilbao bajo el cobijo de la nueva Diputación vizcaina y el Ayuntamiento de esta villa, ambos de ese mismo talante, hasta que los carlistas, después de la sublevación preliminar de abril de 1872, durante el tránsito del eclipse de la Monarquía amadeísta y el despegue de la I República desencadenaran un exitoso levantamiento que les permitió dominar, con excepción de algunas ciudades, todo el País Vasco y Navarra ${ }^{25}$.

Entonces, en septiembre de 1873, apoyando ya la empresa de la Restauración liderada por Antonio Cánovas del Castillo, emigró a Madrid. Así, no sufrió el sitio de Bilbao y, por tanto, quedó al margen de la intensa nacionalización liberal generada durante la defensa de la villa, pero tampoco vivió en la capital los momentos revolucionarios más álgidos, ya que, al poco de llegar, la República se reorientó muy conservadoramente y al concluir 1874 comenzó el

23 José Extramiana, Historia de las guerras carlistas, Haramburu Editor, San Sebastián, 1980, vol. II, pp. 42-43, 162 y 238-240 y Mikel Urquijo Goitia, Liberales y carlistas. Revolución y Fueros Vascos en el preludio de la última guerra, Servicio Editorial de la Universidad del País Vasco, Bilbao, 1994, pp. 13-35, 42-47 y 214-218.

24 Montserrat Amores García, Antonio de Trueba...op. cit., pp. 34-35 y Julio Aróstegui, Jordi Canal y Eduardo González Calleja, El carlismo y las guerras carlistas. Hechos, hombres e ideas, La Esfera de los libros, Madrid, 2003, pp. 12, 16 y 22.

25 Joseba Agirreazkuenaga, "Patriotismo foral y gobierno de Bizkaia...op. cit., pp. 319-323; José Extramiana, Historia de las guerras...op. cit., vol. II, pp. 346-347; Lucien Louis-Lande, "Un conteur espagnol..., op. cit., pp.358; Antonio Trueba, Cielo con nubecillas. Recuerdos de la vida rural y familiar de Vizcaya, Imprenta de A. Pérez Dubrull, Madrid, 1871, p. IX; y Mikel Urquijo Goitia, Liberales y carlistas...op.cit., pp. 54-61. 
reinado de Alfonso XII. Durante esta segunda etapa madrileña, el narrador vizcaíno renovó antiguas amistades, como las de Eugenio Hartzenbusch, Luis Eguílaz, Pedro Antonio Alarcón, Antonio Arnao y Carlos Pravia, y adquirió otras nuevas, como las de Carlos Frontaura, Manuel Ossorio y Bernard, Teodoro Guerrero, Narciso Serra y Ricardo Sepúlveda. En su mayoría eran periodistas y escritores situados de una u otra manera en la órbita del conservadurismo y vinculados al partido alfonsino. Así, muchos de ellos, incluido el narrador vizcaíno, participaron en el Álbum poético editado en marzo de 1876 en homenaje al nuevo monarca ${ }^{26}$.

Antonio Trueba, que agregaba a estos rasgos el aditamento de un fuerismo católico inquebrantable, durante este sexenio en su labor como cronista siguió documentándose para la elaboración de la Historia General de Vizcaya, que estaba preparando. Pero, para poder subsistir, intensificó su labor periodística, destacando sus colaboraciones en La Época, La Ilustración Española y Americana, El País Vasco-Navarro y, sobre todo, en 1873 en el periódico fuerista, alfonsino y canovista fundado y dirigido por su amigo Sabino Goicoechea, El Correo Vascongado, del que fue primer redactor ${ }^{27}$.

En su labor literaria, que en este tiempo también se dilata y es objeto principal de nuestro análisis, se producen algunos cambios con respecto a la época anterior. Se aprecia un intento por parte de Antonio Trueba por superar la narración corta y hacer novelas, pero -como señala Lucien Louis-Lande- no lo consigue, ya que al final no son más que cuentos largos con multitud de digresiones, utilizadas para introducir distintas reflexiones y aseveraciones sobre diferentes temas ${ }^{28}$. Además, se advierte cierta irritación en su talante, una verdadera indignación por los cambios y transformaciones producidos a partir de la Gloriosa y también por la nueva guerra civil para él provocada por ellos ${ }^{29}$. Por lo tanto, se asiste a una politización de su obra, orientada, por un lado, a denunciar las alteraciones ocasionadas por la Gloriosa y, por otro lado, siguiendo la trayectoria del final de la etapa anterior, a adoctrinar en el foral-catolicismo en claro detrimento del primigenio nacional-catolicismo.

A este apartado corresponden las aportaciones realizadas entre 1871-1872 a la colección de novelas dedicadas a la juventud editadas por Antonio Pérez Dubrull y recogidas bajo el título de Biblioteca de la familia cristiana, destacando Cielo con nubecillas, recuerdos de la vida rural y familiar de Vizcaya; narración, que viene a ser una especie de apéndice del Bosquejo de la organización social de Vizcaya, en la que al insistir en la imagen armónica y feraz del agro vizcaíno pretende, si no evitar, sí reducir la emigración vasca a ultramar. Este mismo

26 Montserrat Amores García, "Antonio de Trueba y su obra literaria"...op. cit., pp. 106-107; Ricardo Becerro de Bengoa, Trueba...op. cit., pp. 44-46; Fernando Molina Aparicio, La tierra del martirio...op. cit., pp. 198-199; y Antonio Trueba, Mari-Santa...op. cit., p. 2 y Cuentos del hogar...op. cit., p. 3.

27 José Ángel Arrate Jorrin, “Antonio de Trueba. Una vida entre dos guerras” en Javier Barrio Marro et al, Antonio de Trueba (1819-1889). Cronista de Bizkaia / Antonio de Trueba (1819-1889). Bizkaiko kronista, Museo de Las Encartaciones/ Juntas Generales de Bizkaia, Bilbao, 2020, pp. 211-212; Antonio Trueba, Cuentos del hogar...op. cit., p. 4; y Mikel Urquijo Goitia, Dos aproximaciones...op. cit., p. 38.

28 Lucien Louis-Lande, “Un conteur espagnol...op. cit., pp. 359.

29 José Antonio Ereño Altuna, Antonio de Trueba...op. cit., pp. 110 y 136. 
trasunto parece que quiso desarrollar en la inconclusa Historia de dos almas, una negra y otra blanca (1876). También en este bloque deben incluirse las otras colaboraciones a aquella colección -recogidas después en 1878 en Cuentos de madres e hijos-, Narraciones populares (1874), Cuentos del hogar (1875) y, sobre todo, Mari-Santa: cuadros de un hogar y sus contornos (1874), un auténtico éxito editorial que retrata en el Bilbao de entonces a una mujer ejemplar, cristiana, bondadosa y honrada, como para el escritor vasco era su madre y la mayoria de las vizcainas. En el primero de los apartados deben integrarse las obras que constituyen auténticas diatribas contra la revolución democrática y la modernización: El gabán y la chaqueta (1872) y Alrededor de Madrid (1874; reeditado en 1878 como Madrid por fuera), situadas en Madrid; y El redentor moderno (publicada en 1875 por entregas en el periódico canovista La Época y en 1876 como libro), que viene a ser una especie de historia contrafactual en la que presenta el panorama desolador que, según él, hubiera supuesto para el País Vasco la implantación en su integridad de las innovaciones de la Gloriosa ${ }^{30}$.

Pues bien, a partir de estas narraciones y de los principales artículos de opinión de El Correo Vascongado, en los que Antonio Trueba estaba particularmente implicado, la imagen que muestra del sexenio 1868-1874 en su conjunto es la de la más absoluta desolación: "seis años de espantoso desorden moral y material". Para él la única y exclusiva causa es la revolución de septiembre de 1868, que pone fin a treinta años de prosperidad $y$ engrandecimiento con el acto de ingratitud y deslealtad del destronamiento de Isabel II, llevado a cabo, salvo en el País Vasco y Navarra, en el resto del Estado y particularmente en Madrid, cuando cuya afirmación y desarrollo como capital se habia debido a esa Monarquía ${ }^{31}$.

Una vez que se hace "rodar por el suelo el trono secular", se proclama "la inesperada y portentosa nueva de que no habia Dios". De esta manera, desde una posición de vehemente militancia católica ortodoxa, recibe Antonio Trueba el reconocimiento de la libertad de cultos realizado por la Gloriosa. Lo hace así y con expresiones como que se "anuncia que Dios no existe, ni el alma humana es inmortal, ni la Madre de Jesús ascendía sin mancilla a los cielos" porque para él y para sus correligionarios conservadores hasta entonces no se habia llegado tan lejos ${ }^{32}$. Incluso en la revolución gaditana, que para Antonio Trueba se encuentra

30 Montserrat Amores García, "Antonio de Trueba y su obra literaria”...op. cit., pp. 124-125.

31 Antonio Trueba, Mari-Santa...op. cit., pp. 77 y 217 y Madrid por fuera [Reedición Alrededor de Madrid, 1874], Agustín Jubera, Madrid, 1878, pp. 300-301 y 307. En el número 2 de El Correo Vascongado del 17 de abril de 1873 aparece publicada una carta de Antonio Trueba en la que declina formar parte en la redacción del diario, pero ofrece a cambio sus "humildes trabajos literarios, siempre con [su] firma al pié". Pero las cosas no fueron así, como se recoge en una carta remitida el 23 de abril de 1876 al director de El Imparcial y publicada en Irurac-Bat de 25 de abril de 1876, en la que señala: “(...) un periódico francamente alfonsino, que había fundado y dirigía don Sabino Goicoechea y entre cuyos primeros y más asiduos redactores me contaba yo. Ibame quizá la vida en que no se supiese que los artículos de fondo estaban casi siempre escritos por mí y no pude evitar que carlistas y republicanos me designasen como su autor (...)" (en Alberto Ciaurriz Belzunegui, La abolición de los Fueros vascos a través de la prensa, Editorial Auñamendi, San Sebastián, 1976, vol. I, pp. 225-229).

32 Antonio Trueba, El gabán y la chaqueta, Imprenta de T. Fortanet, Madrid, 1872, p. 12, MariSanta...op. cit., p. 25 y Madrid por fuera...op. cit., p. 36. 
en el origen de ésta y de todas las anteriores, porque, a pesar de haber estado educados sus mentores "en el enciclopedismo francés, que no solo es la negación de toda fe religiosa sino también la de toda justicia social", mantiene la exclusividad católica y la intolerancia religiosa ${ }^{33}$. No así los revolucionarios de 1868, cuya política religiosa -fundada, además de en la libertad de cultos, en el matrimonio civil, la supresión de algunas órdenes, la expulsión de los jesuitas, etc.- provoca para el autor vizcaíno la ruptura de "la unidad religiosa de nuestra patria, que ya no se puede dar el santo nombre de católica". Con ello, al clausurar siglos de historia que habian definido la identidad de España y de los españoles, se abre la puerta -subraya- a las confesiones falsas, al quebranto de la única verdadera y a la pérdida del sentimiento religioso ${ }^{34}$. Y de ahí el panorama tan luctuoso que pintara a finales de junio de 1873 El Correo Vascongado en el editorial titulado "Sacrílegos": “(...) Si en España no hubiera visto derribar templos, atropellar por todos los medios a los sacerdotes, dejar morir de hambre al clero, blasfemar de Dios desde la hoja volante callejera a la Gaceta Oficial, desde el consistorio municipal hasta la tribuna parlamentaria (...)"35.

Pero para el narrador vizcaíno la libertad de cultos y las medidas conexas no afectan sólo a la Iglesia y a la religión católica, sino a la sociedad en su conjunto porque facilitan la entrada de "las ideas inmorales y disolventes", como las que profesan los demócratas, republicanos, federales, socialistas o internacionalistas ${ }^{36}$. Con ellas, alterándose "el orden natural y lógico de las cosas" -señala El Correo Vascongado-, se permite la máxima participación popular en los asuntos públicos ${ }^{37}$. Algo que no es del agrado de Antonio Trueba porque, a pesar de la simpatía y afición que siente por todo lo popular, considera que "la opinión debía ser hija de la razón y, la que no lo era, no valía nada". Desde esta óptica conservadora, es contrario al sufragio universal y estima que su aplicación impide contar con hombres de prestigio y formación, y provoca, según el citado diario, una especie de "despótica dictadura" de los de abajo, del "populacho."38 Así lo contempla, por un lado, en las sucesivas formulaciones politicas que, como la Constitución de 1869 -que "sabe Dios de dónde es", apunta-, la sustitución de "la gloriosa Corona de España", primero, por "la insostenible" Monarquía "extranjera e improvisada" y, después, por "el gorro frigio" republicano o la proyectada organización territorial federal, "arrancan de raíz los fundamentos que han servido de base a la existencia de la nación

33 Editorial:" El decano del federalismo" (s.f.), El Correo Vascongado, 11-06-1873.

34 Antonio Trueba, El gabán y la chaqueta...op. cit., p. 468 y El redentor moderno, Imprenta y Librería de Miguel Guijarro, Madrid, 1876, pp. 326-327. Hay un importante seguidismo de los planteamientos del famoso folleto Jaungoicoa eta foruac. La causa vascongada ante la revolución española (Vitoria, 1869) del carlista Arístides de Artiñano. Al respecto, Coro Rubio Pobes, “¿Qué fue del oasis foral?", Ayer n $^{\circ} 38,2000$, pp. 80-81 y para comprobar la cultura política compartida entre el fuerismo moderado y el carlista Vicente Garmendia, La ideología carlista (1868-1876). En los origenes del nacionalismo vasco, Diputación Foral de Guipúzcoa, San Sebastián, 1985, pp. 5787; y Fernando Molina Aparicio, La tierra del martirio...op. cit., pp. 124-125 y 127-133.

35 Editorial: “Sacrílegos” (s.f.), El Correo Vascongado, 24-06-1873.

36 Antonio Trueba, Cuentos del hogar...op. cit., p. 269.

37 Editorial: "De mal en peor" (s.f.), El Correo Vascongado, 19-07-1873.

38 Antonio Trueba, Narraciones populares...op. cit., p. V y Madrid por fuera...op. cit., pp. 195-197 y 298; y Editorial: "Las dos hipocresias" (s.f.), El Correo Vascongado, 15-06-1873. 
española"39. Y también lo observa, por otro lado y sobre todo, en el desarrollo práctico, que resume en una simple equivalencia: "revolución o exceso de libertad"; un amplio espectro de libertades a las que, según Antonio Trueba, los españoles no están acostumbrados y menos aún formados para su ejercicio responsable y, por ello, derivan en "un abominable libertinaje", es decir, "que los mandamientos de ley de Dios se vuelven al revés (...), que de Dios, de la sociedad, de la familia y de la propiedad no queda siquiera rastro (...) que en nombre del progreso y la libertad se señorean del mundo la barbarie y la esclavitud"40. Así, para el escritor vizcaíno "la anarquía más espantosa reina en España" y lo ilustra aportando el ejemplo de Madrid, que tilda de "capital de la podredumbre política", y de lugares de ficción (como Corretania de los Cuentos del hogar "Los corretones" o Isgalde de $E l$ redentor moderno), recreados revolucionariamente con robos, asesinatos, motines, atropellos, fraudes, corruptelas, ilegalidades, juegos, alcoholismo, prostitución, holgazaneria, etc. ${ }^{41}$ En definitiva, según El Correo Vascongado, existe un desconocimiento absoluto del principio de autoridad y España es el hazmerreír de todo el mundo ${ }^{42}$.

Frente a esta situación el País Vasco hasta 1870 representa -en palabras de este mismo diario- "un delicioso oasis en el desierto revolucionario de España". Así, en el verano -puntualiza el artículo del citado periódico- sus playas y balnearios se llenan de forasteros, sus pueblos prosperan, su vida fabril e industrial se desarrolla, sus ferrocarriles y carreteras rebosan de animación, en fin, "que del Ebro acá reinan el progreso y la dicha contrastando con el retroceso y la desventura que reinan del Ebro allá"43. Pues bien, para Antonio Trueba, esto se debe, en primer lugar, a la gratitud y lealtad de los vascongados a Isabel II, bajo cuyo reinado se habian vivido treinta años de paz y prosperidad. En segundo lugar, la tranquilidad vasca también deriva del disfrute ancestral de un régimen de libertades conferido por la ordenación foral, que hace que las conquistas de la Gloriosa no sean tan significativas como para los demás españoles. Y, en tercer lugar, el País Vasco no se suma al movimiento revolucionario por su "profundo sentimiento religioso" que, para Antonio Trueba, es la base de todos los sentimientos honrados", que hacen que -siguiendo la opinión de Juan Eugenio Hartzenbusch- imperen "el bienestar, buen gobierno, moralidad, sensatez y paz"44.

Casi es esta misma razón la que ocasiona que el sosiego se quiebre esporádicamente desde 1870 y de forma incontrovertible a finales de 1872 porque la guerra carlista, que entonces estalla, tanto para Antonio Trueba como para $E l$

39 Editoriales (s.f.) de El Correo Vascongado, 26-04, 1-05 y 10-07-1873 y Antonio Trueba, El gabán y la chaqueta...op. cit., p. 319.

40 Antonio Trueba, El gabán y la chaqueta...op. cit., p. 443, Narraciones populares...op. cit., p. 152 y Cuentos del hogar...op. cit., pp. 168, 174, 199 y 269.

41 Antonio Trueba, El gabán y la chaqueta...op. cit., pp. 402 y 488, 1876, p. 38 y Cuentos del hogar...op. cit., p. 199. Existe una plena coincidencia con otros fueristas como Miguel Loredo o Fidel Sagarminaga (al respecto, Fernando Molina Aparicio, La tierra del martirio...op. cit., p. 252).

42 Editoriales (s.f.) de El Correo Vascongado, 2-05 y 10-07-1873.

43 Editorial: "Las dos guerras” (s.f.) de El Correo Vascongado 4-05-1873.

44 Antonio Trueba: El gabán y la chaqueta...op. cit., pp. 464-466; Mari-Santa...op. cit., pp. 192 y 217; Narraciones populares...op. cit., p. 47; El redentor moderno...op. cit., p. 38; y Cuentos del hogar...op. cit., p. 207. 
Correo Vascongado, es consecuencia de la revolución de 1868 y de la aplicación a las provincias vascas de sus medidas, particularmente de las orientadas a la laicización y reordenación de la iglesia. Así, para ambos, la guerra carlista y la revolución Gloriosa son dos caras de la misma moneda y se retroalimentan la una a la otra: "La causa de Don Carlos ha renacido al amparo de la anarquia"; "el carlismo armado sirve de excelente pretexto al gobierno republicano, como sirvió al amadeista, para entregarse a todos los desafueros e ilegalidades que se le antojen". Igualmente, ninguno de ellos considera que los Fueros hubieran influido en la rebelión carlista; otra cosa, puntualiza el escritor vizcaíno, son los "contrafueros", sobre los que volveremos al tratar de la relectura que realiza antes de la abolición foral de la situación del País Vasco desde 183945.

Obviamente, Antonio Trueba maldice este recurso a las armas, esta "guerra de hermanos contra hermanos". Su rechazo de la violencia, que le había obligado abandonar la tierra natal en dos ocasiones, le hace cargar las tintas sobre los excesos, abusos y extorsiones cometidos por los carlistas. También los subraya $E l$ Correo Vascongado, mostrando lo cruento de su actuación, especialmente de "los santacruzos" o intransigentes del carlismo, de aquellos que, siguiendo el ejemplo de la partida sanguinaria liderada por el cura Manuel Santa Cruz, hacen la guerra de manera brutal y bárbara. Esta extralimitación se debe en parte para ambos a la carencia de "jefes de arraigo y de prestigio en el país" y a la propia ineptitud del monarca que, según el autor vasco, "quería imitar a los reyes absolutos del tiempo de Mari Castaña"46.

Son bastante más condescendientes con los combatientes de base del carlismo que, aunque consideren que, a diferencia de los de Cataluña, en su mayoria fueran forzosos, asumen su ideario, que es el que domina en el espíritu público de las provincias vascas ${ }^{47}$. Es lo que El Correo Vascongado llama "el carlismo respetable", es decir, aquellos principios y sentimientos que "nos merecen no ya respeto, sino simpatía", y también a Antonio Trueba por su clara coincidencia ideológica. Así, para esta publicación, el grueso de los aldeanos que figuran en las filas del pretendiente actúan de buena fe, creyendo salvar la patria del naufragio en que todo amenaza perecer: la religión, la monarquía, la familia, la propiedad, la justicia, la libertad y el sosiego público. Y, para el escritor vizcaíno, es el "único refugio" frente a "los crímenes y la locura de la revolución de $1868 " 48$.

Desde esta perspectiva conservadora es, por un lado, bastante más factible salvar al carlismo. Más aún si, como hace ese diario, se realiza una comparación entre la que califica guerra social (la cantonal y republicana social) extendida

45 Editoriales (s.f.) de El Correo Vascongado, 25-05 y 5-07-1873 y Antonio Trueba, Cuentos del hogar...op. cit., pp. 395-404.

46 Editoriales (s.f.) de El Correo Vascongado, 29-04 y 2-.06-1873; y Antonio Trueba, Cuentos del hogar...op. cit., pp. 4, 14 y 106, y "Por qué hay un poeta más y un labrador menos", Hermes. Revista del País Vasco, n 57, 1920, pp. 209, 211 y 218.

${ }^{47}$ Editorial: "El eclecticismo carlista" (s.f.), El Correo Vascongado, 6-06-1873 y Antonio Trueba, Cuentos del hogar...op. cit., p. 156.

48 Editoriales (s.f.) de El Correo Vascongado, 7-06 y 2-07-1873; y Antonio Trueba Historia de dos almas...op. cit., p. 10. La coincidencia de estos principios con el carlismo en Julio Aróstegui, Jordi Canal y Eduardo González Calleja, El carlismo y las guerras carlistas...op. cit., pp.77-79 y Coro Rubio Pobes, “¿Qué fue del oasis foral?... op. cit., pp. 79-80. 
durante el verano de 1873 por Andalucía y Levante y la guerra carlista, y se llega a la conclusión de que aquella es "cien mil veces más funesta" porque pretende la "disolución social y la conculcación de todo derecho divino y humano", mientras que ésta "entraña en su fondo la única esperanza de que para la patria vuelvan los buenos tiempos." En definitiva, concluye el artículo "El norte y el mediodia", aquella, "la guerra demagógico-social", es un conjunto de aberraciones morales e impulsos pasionales, mientras que ésta, la carlista, salvo por el hecho de la guerra civil, "es la exageración del sentimiento de bien"49.

Con esta visión tan empática del carlismo, por otro lado, resulta más viable la propuesta de reconciliación planteada por el periódico y por el narrador vizcaíno en torno a la empresa de la restauración y la figura de Alfonso XII. Dada la adhesión y fidelidad profesada por ambos a Isabel II, consideran a su hijo "el legítimo y verdadero rey de los españoles" y aspiran a que con él se recobre "la paz y la prosperidad que se alcanzó en el glorioso reinado" de aquella. Por eso, el advenimiento de Alfonso XII al trono, que para ellos es la única solución al dilema entre la revolución y el carlismo, supone el retorno de la cultura moderada, es la restauración "de la paz pública, de la libertad bien entendida, de la justicia, del respeto a la propiedad, del culto de Dios, que es el culto del bien"50.

A la espera de que la restauración prosperara y, consolidada, se pudiera recuperar "el paraiso foral" interrumpido por la guerra carlista, Antonio Trueba en su obra de ficción reafirma sus parámetros fundamentales y procede adecuarlos a los nuevos tiempos. Para él, "el amor a Dios, a la patria, a la familia y al trabajo" constituyen los pilares maestros de ese paraíso, los hitos principales de su literatura y las señas de identidad de las Vascongadas. Como ante todo cuenta la primacía la religión, los otros términos, que siempre se contemplan bajo su prisma, deben ser "como Dios manda"51. Pues así nos acercaremos a ellos, con ese carácter sacralizado que les confiere el narrador vasco.

El primero de ellos, la patria, habitualmente se identifica en Antonio Trueba con el lugar donde uno ha nacido, con la "aldea nativa". De ahí que haga afirmar al jauntxo Ignacio, uno de los protagonistas de Cielo con nubecillas, que "la patria del hombre es el mundo (...), pero el mundo empieza donde uno ha nacido (...), allí, donde principian mis deberes de amar, de agradecer y de proteger, principia mi patria; antes que Vizcaya Loreaga; antes que España Vizcaya; antes que el mundo España". Este amor a la patria chica o este "patriotismo de campanario", como lo califica Lucien Louis-Lande, adquiere toda su dimensión si tenemos en cuenta que Loreaga, como todos los pueblos vascos retratados por el autor vizcaíno, principalmente los de Las Encartaciones, es un lugar idílico. Llamado así, "sitio de flores", porque en primavera parece un "país nevado con el manto de flores", cuenta con un núcleo central alrededor de una parroquia y dispersas por

49 Editorial: "El norte y el mediodia” (s.f.), El Correo Vascongado, 17-07-1873. Siguen, al igual que otro fuerista moderado como Juan Ernesto Delmas, la disyuntiva planteada por el carlista Vicente Manterola en el conocido folleto D. Carlos o el petróleo (Madrid, 1871) y prefieren, como él, la tradición a la anarquía. Al respecto, Fernando Molina Aparicio, La tierra del martirio...op. cit., pp. 126-127.

50 Editoriales (s.f.) de El Correo Vascongado, 22-05, 7-06 y 3-07-1873 y José Extramiana, Historia de las guerras...op. cit., vol. II, pp. 103 y 111.

51 Antonio Trueba, Cielo con nubecillas...op. cit., p. X; El gabán y la chaqueta...op. cit, p. 455 y El redentor moderno...op. cit., pp. 5, 12 y 393. 
el valle siempre verde atravesado por un riachuelo distintos caseríos con sus heredades sombreadas por castaños, robles y nogales ${ }^{52}$.

El estereotipo de aldea de Antonio Trueba también cuenta con unos vecinos virtuosos y cuasi-inmaculados que, acordes con el paisaje paradisíaco, son los que la hacen "tan sana, alegre, rica y feliz". Así es porque, salvo cuando el modelo se trunca por la guerra civil y que tanta exasperación produce a nuestro autor, en la aldea se consigue una perfecta armonía entre el medio físico y las familias que la forman. De esta manera, a través del esfuerzo y del trabajo honrado y resignado en el campo y de la sencilla y tranquila vida en el hogar familiar es como para el escritor vizcaíno se alcanza la auténtica felicidad doméstica. Por eso en sus narraciones no se cansa de idealizar la vida cotidiana de los caseríos y de ligarla con las buenas costumbres y tradiciones, el amor a la familia, el respeto a la propiedad y a las jerarquías reconocidas, etc., formando así-como recoge en el prólogo de Mari Santa- "una coleccioncita de cuadros de familia, más o menos apacibles y sonrosados"53.

Pero el universo aldeano de Antonio Trueba, en el que predominan "las almas blancas y las caras sonrosadas" 54 , está incompleto si se omite la religión. Gracias a ella para el autor se logra la anterior armonía y también que en la convivencia vecinal impere la concordia y se superen todos los conflictos y adversidades. Así, los personajes de Antonio Trueba parece que están permanentemente guiados por el "Catecismo del Padre Astete", que no sólo les hace cumplir fervorosamente los sacramentos y los ritos y celebraciones religiosas, sino que sujeta su conducta y principales pensamientos a la fe católica $\mathrm{y}$ a las directrices de la Iglesia. Por eso en las narraciones de nuestro autor el templo y el cura párroco ostentan una posición nuclear en la vida comunitaria. El primero no sólo es el lugar donde acuden los vecinos a rezar, realizar plegarias o a la celebración de los oficios religiosos, sino que, además, bajo su pórtico, es el sitio de esparcimiento y de charla de los hombres de la aldea. También es punto de arranque de las festividades del pueblo con una procesión de la virgen o santo titular, continuadas después con una comida fraternal, juegos entretenidos (partidos de pelota) y bailes que, aunque "sencillos y honestos" -como subraya el escritor vizcaíno-, siempre cuentan con la presencia escrutadora del cura55. Éste, dado que lo que se persigue es que "el cielo moral sea el más sereno del mundo", ostenta la mayor auctoritas del pueblo y siempre en Antonio Trueba es ejemplo de vida: "El [párroco] de Urtiaga (...) -retrataba en El gabán y la chaqueta- era celoso en el desempeño de su sagrado ministerio, caritativo, de genio apacible, olvidadizo de su propio bien, amante del ajeno, indulgente con todos, severo con

52 Lucien Louis-Lande, "Un conteur espagnol...op. cit., p. 402; y Antonio Trueba, Cielo con nubecillas...op. cit., pp. 11-12 y 110.

53 Antonio Trueba, Narraciones populares...op. cit., p. 265; Cielo con nubecillas...op. cit., pp. 4546 y Mari-Santa...op. cit., p. 7.

54 Antonio Trueba, Historia de dos almas...op.cit., p. 8.

55 Antonio Trueba, Cielo con nubecillas...op. cit., pp. 115 y 157-158; El gabán y la chaqueta...op. cit, pp. 470-473; y Cuentos del hogar...op. cit., p. 309. También, Javier Barrio Marro y Goio Bañales García, "Antonio de Trueba y su visión de Las Encartaciones", en Javier Barrio Marro et al, Antonio de Trueba (1819-1889). Cronista de Bizkaia / Antonio de Trueba (1819-1889). Bizkaiko kronista, Museo de Las Encartaciones/ Juntas Generales de Bizkaia, Bilbao, 2020, pp. 55 y 84-85 
sí propio [sic], parco en la mesa, sencillo y placentero en su trato, y extraño a toda bandería, como no fuese para predicar la paz y la conciliación. Así no había en la aldea quien no le respetase y amase" 56.

En las narraciones de Antonio Trueba ni hay religiosos carlistas, que son los más, ni tienen influencia alguna en la adhesión de los vecinos a las filas del pretendiente, que resultó fundamental. En cambio, sí tiene cabida y mucha la repercusión de los cambios revolucionarios en las ciudades, principalmente en Madrid, en claro contrapunto a la reseñada vida ejemplar de los pueblos vascos. El amor a la tierra natal y la inmensa nostalgia de la ausencia producen en el escritor vizcaíno -como afirma en Madrid por fuera- "una aversión invencible a lo que no sé si se llama vida urbana", que se incrementa, particularmente refiriéndose a la capital, tras la Gloriosa. De ahí que el recuerdo que tiene sobre su primera larga estancia resulte bastante más gratificante que la visión que ofrece de su segunda residencia en Madrid.

Para empezar, para él, Madrid "carece de amor y orgullo local" porque está formado por gentes que han venido de otros lugares que, al criarse y mantener hábitos extra-madrileños, les resulten indiferentes los beneficios o la gloria que se le pueda dar o quitar a la capital. Además, considera que muchos de los que vienen a la capital están muy lejos de ser lo más a propósito para formar un pueblo virtuoso y lo hacen animados por "innobles ambiciones o de espíritu inquieto" 57 . De ahí, que en El gabán y la chaqueta recree: de una parte, el Madrid lúgubre de las casas de huéspedes y de los holgazanes, truhanes, ladrones y prostitutas, acompañados de los gritos de dia de vendedores ambulantes y de noche de serenos y borrachos, de "horribles blasfemias" y olores apestosos de los callejones; y, de otra parte, el Madrid de las apariencias, de aquellos caballeros particulares conocidos en la llamada buena sociedad madrileña, que acuden a los estrenos teatrales, a los conciertos, a los casinos, a las casas de juegos, a los paseos y a la Puerta del Sol, con traje y maneras aristocráticas y muy pechisacados, zumbando al oído con aíre de Tenorios a las mujeres hermosas y muy arregladas, y fallando ex cátedra de casi todo, pero incapaces de crear nada58. En definitiva, "Madrid es un libro de inmoralidad abierto a todo el que tiene ojos en la cara", afirma en "El pecado natural" de la colección de Cuentos del hogar. En él, Antonio Trueba se centra en un matrimonio modélico y muy religioso que, para evitar que sus hijos siguieran la vida depravada y licenciosa que ellos habían llevado de solteros en el disoluto Madrid, los envían a cargo de un tío cura al pueblo de Valpacífico, llamado así porque desde que lo visitó Santa Teresa reina la bondad y no hay pecado ${ }^{59}$.

Para el narrador vasco, Bilbao, a pesar de "pueblo animadísimo por su mucho comercio y concurrencia de forasteros", está muy lejos de asemejarse a Madrid, sin que por ello nada tenga que "envidiar a las de las capitales más

\footnotetext{
56 Antonio Trueba, Cielo con nubecillas...op. cit., p. 157 y El gabán y la chaqueta...op. cit., p. 36. Para la influencia comunitaria en las Vascongadas de la parroquia y del cura que está a su frente se puede seguir a Coro Rubio Pobes, La identidad vasca en el siglo XIX...op. cit., pp. 391-395 y 425-429.

57 Antonio Trueba, Madrid por fuera...op. cit., pp. 7 y 302-303.

58 Antonio Trueba, El gabán y la chaqueta...op. cit., pp. 72-73, 77-78, 99-101 y 416-419.

59 Antonio Trueba, Cuentos del hogar...op. cit., pp. 78-103.
} 
adelantadas y populosas". Se debe en gran medida, según él, en primer lugar, al propio modelo foral que iguala a todos los municipios vizcaínos, con independencia de su población o por ostentar la capitalidad provincial, y, en segundo lugar, porque "apenas se han alterado aún los buenos usos $\mathrm{y}$ costumbres de la familia". En definitiva, que la revolución gloriosa apenas si ha hecho mella. Por eso, Bilbao está "limpísimo y ordenado por su excelente policía y administración municipal; de vecindario rico, hospitalario, generoso y culto; cuya clase popular nunca pierde el buen humor ni la afición al trabajo, ni falta nunca al respeto debido al superior en autoridad o saber"60.

Gran parte de estos benéficos efectos provienen para Antonio Trueba de la familia, institución que, "creada por [la] sabia mano [de Dios] y bendecida por su santo espíritu", considera nuclear y viene a ser una segunda edición del paraíso terrenal. De esta manera, santificada, el modelo de familia que preconiza es el tradicional patriarcal, asentado en la "superioridad moral y física" del hombre, al que le incumbe el mantenimiento de sus miembros mediante el trabajo, la defensa del honor y del apellido familiar y la perpetuación del patrimonio de la casa solar, y en la supeditación de la mujer, a la que corresponde el buen gobierno del hogar, el cuidado y educación de los hijos y el amor, respeto y ayuda al marido ${ }^{61}$.

Estos son algunos de los rasgos con los que cuenta "una santa madre de familia" como Mari Santa. Antes de perfilarlos más, el escritor vizcaíno en Cielo con nubecillas ya había incidido en una cuestión que le produce grandes desvelos, la virginidad, y lo había hecho rememorando dos tradiciones, la de la rueca que corona el arreo de la novia y la sabanilla blanca. Así, una vez "trocada la condición de virgen por la no menos santa y noble de esposa y madre"62, profundiza en ésta a través de Mari Santa. En ella quiere condensar el nombre de amá, "tan dulce y grato para los vascongados", y lo hace en la narración haciéndole un espejo de su madre y contraponiéndola a su hermana tanto en lo físico como en moral. Así, aunque no muy favorecida por la naturaleza (mejor porque según afirmación bastante gratuita de Antonio Trueba una "mujer hermosa casi siempre carece de talento y de bondad"), Mari Santa no sólo es una mujer como Dios manda, sino modelo en lo moral. De esta manera, cumpliendo sobradamente con el gobierno de la casa y de la familia, es una ferviente católica, profesa una entrañable adhesión a Isabel II "por afinidad de corazón de mujer y madre", es cariñosa, bondadosa, abnegada, generosa e indulgente, y llora, compadece, consuela y alivia los infortunios y males ajenos, haciéndolos propios $^{63}$. En definitiva, el modelo de mujer que presenta Antonio Trueba se encuentra a medio camino entre "el ángel del hogar", arquetipo de la feminidad

${ }^{60}$ Antonio Trueba, Mari-Santa...op. cit., p. 153; Madrid por fuera...op. cit., p. 29; El redentor moderno...op. cit., p. 154; e Historia de dos almas...op.cit., pp. 8-9. Para esta visión dulce de Bilbao Montserrat Amores, "Antonio Trueba y Bilbao" en Adolfo Arejita et al., Bilbao. El espacio lingüístico. Simposio 700 Aniversario. Bilboren 700. Urteurrena. Hizkuntza gunea Sinposioa, Universidad de Deusto, 2002, Bilbao, pp. 246-250.

61 Antonio Trueba, Mari-Santa...op. cit., p. 253 y 1876, p. 311; y Javier Pérez Núñez, "Didáctica para una nación católico-conservadora...op.cit., pp. 15-16.

62 Antonio Trueba, Cielo con nubecillas...op. cit., pp. 50 y 69.

63 Antonio Trueba, Mari-Santa...op. cit., pp. 27, 32, 145 y 197. También Montserrat Amores Garcia, "Antonio de Trueba y su obra literaria"...op. cit., pp. 137-138. 
hegemónico en la cultura liberal, y la "mujer católica" del neocatolicismo conservador, pero con un papel menor al asignado en la empresa de catolización de la sociedad ${ }^{64}$.

Pero, todo hay que decirlo, Mari Santa ejerce principalmente aquellas virtudes con los pobres, las criadas, la costurera y los inquilinos y colonos porque pertenece a la cúspide social de Bilbao. Así, casada con Juan Gorostiza, rico indiano vizcaíno, poseen una compañía comercial en Argentina y Cuba y una docena de caserias dispersas por la provincia, y tienen "los cuarteles de invierno" en la zona más suntuosa entonces de El Arenal bilbaíno, La Estufa. Aunque cumplen con los rasgos paternalista, altruista y benefactor que Antonio Trueba confiere a los caseros vizcaínos (en este caso remarcados por la presencia de Mari Santa), se distancian algo de su modelo clásico en el que las "familias finas" residen en los pueblos, cuyo trato sirven para "cultivar y suavizar el entendimiento y costumbres de la gente rústica", y las inversiones se destinan casi exclusivamente al sector primario 65 .

Por el contrario, estas pautas sí se cumplen en la narración Cielo con nubecillas, en la que a Ignacio, uno de sus protagonistas, se le puede caracterizar como el prototipo para nuestro autor de hombre vizcaíno, de baserritarra. En este caso, lo contrapone a su hermano menor, Julián, que emigra a América, mientras él, en calidad de heredero del caserío familiar, permanece en la aldea natal de Loreaga. Aquí, Ignacio no se limita como sus antecesores a incrementar el solar, sino que se "empeña en ser un indiano en Vizcaya". Así, con una formación muy modesta, lo consigue sobre todo por su gran afición al trabajo, pero también por su iniciativa emprendedora altruista preocupada no tanto por el beneficio particular como por el general de la aldea y de sus convecinos. Pues bien, mediante la introducción de nuevos métodos de cultivo, logra convertirse en "rico indiano sin ir a las Indias", proporcionando abundantes jornales y haciendo propietarios a muchos vecinos. Esto también le permite formar una feliz familia numerosa con siete hijos, al tiempo que fortalece -y esto es lo importante-la fe religiosa. De esta manera, al igual que ocurre con Mari Santa, Ignacio representa el paradigma de baserritarra católico.

En cambio, su hermano Julián cuando, al cabo de diez años, regresa de América, lo hace muy avejentado, con una fortuna bastante parca y con un notable descreimiento de las costumbres, los grandes valores $y$, fundamentalmente, la religiosidad vascongada. En el caso del indiano de Historia de dos almas, don Roque del Regato, su metamorfosis es tan radical que le hace llamar alma-negra66.

${ }^{64}$ Raúl Mínguez Blasco, Evas, Marias y Magdalenas. Género y modernidad católica en la España liberal (1833-1874), Asociación de Historia Contemporánea/Centro de Estudios Políticos y Constitucionales, Madrid, 2016, pp. 69-72; Ídem, "Liberalismo y catolicismo ante el espejo. La construcción de las feminidades decimonónicas", Inmaculada Blasco Herranz (edit.), Mujeres, hombres y catolicismo en la España contemporánea. Nuevas visiones desde la historia, Tirant Humanidades, Valencia, 2018, pp. 27-45; y Maria Cruz Romeo Mateo, “¿Sujeto católico femenino? Política y religión en España”, Ayer, n 106, 2017, pp. 95-101.

65 Antonio Trueba, Mari-Santa...op. cit., pp. 138, 155-157, 171-173 y 176-179; e Historia de dos almas...op. cit., pp. 120 y 125-127.

66 Antonio Trueba, Cielo con nubecillas...op. cit., pp. 77, 91, 124, 126, 138 y 158-161; у Montserrat Amores García, "Antonio de Trueba y su obra literaria”...op. cit., pp. 141-142. Para su 
De esta manera, con esta obra y, sobre todo, el anterior cuento largo Antonio Trueba intenta corregir en alguna medida el desajuste que, para la armónica comunidad rural plasmada en Bosquejo de la organización social de Vizcaya, representa la importante emigración vasca a ultramar. Así, considera que con las nuevas formas de explotación de los recursos naturales se puede reducir la salida de aquellos hijos o hermanos que no habian sido favorecidos por la sucesión troncal, que para él sigue siendo el modelo dominante en el País Vasco. No reprueba la emigración, pero le genera mucha preocupación por el número, porque muchos no regresan $\mathrm{y}$, cuando lo hacen, bastantes han sufrido un proceso de aculturación, que les produce apostasía de la familia, de la patria y de la religión. Por eso aboga por una emigración ordenada y vinculada a la red de amigos y parientes residentes en América, que sea temporal y pospusiera el matrimonio al retorno, como hizo el marido de Mari Santa ${ }^{67}$.

Cielo con nubecillas, en cuanto que es la continuación de Bosquejo de la organización social de Vizcaya, es un claro alegato del trabajo rural y de la dedicación al campo para seguir afirmando la arcadia feliz vascongada. Sin embargo, Antonio Trueba durante la revolución se abre a la modernización e industrialización y deja de estar cerrado a otras modalidades laborales y otros sectores económicas. Como ya hemos mencionado, para él, como buen conservador, el trabajo es uno de los principios cardinales para organización, orden y progreso sociales. Por eso la conclusión a la que llega en El gabán y la chaqueta es que el trabajo dignifica al hombre, dando igual, siempre que sea honrado, el desarrollado con la inteligencia, o sea, que lleva gabán, o con los brazos, y vestido con chaqueta. Así, lo que pretende en la novela es observar ambas formas laborales a través de las experiencias vividas en Madrid por Martín, joven huérfano vizcaíno con medios suficientes para ponerse gabán. Así, en la capital, al tiempo que cursa la carrera de Derecho, puede dedicarse a su vocación literaria, participando en una asociación y en una tertulia $\mathrm{y}$ consiguiendo cierto reconocimiento con sus escritos. Pero, concluidos los estudios, por las envidias, celos, corruptelas e inmoralidades el "mundo de la inteligencia" se viene abajo y, ante la falta de medios de subsistencia, cambia el gabán por la chaqueta y se pone a trabajar en un taller de forja de hierro. No es capaz de adaptarse y experimentar la dicha que, según el autor, sienten sus compañeros, a pesar de la dureza del trabajo, el corto salario y las miserables condiciones vitales. Apesadumbrado, cae en el indiferentismo hacia los grandes principios y valores, del que le saca su tío, el cura de Urtiaga. Al final, aquí, en su pueblo natal, concluye la narración durante la celebración en su casa de la fiesta de la Asunción de la Virgen con su familia y amigos y satisfecho con su trabajo de abogado. En definitiva, para Antonio Trueba el trabajo siempre es una recompensa y "cada cual debe de estar contento con la ropa que Dios le ha

contextualización Belén Altuna, "La invención del baserritarra como verdadero cristiano vasco", Bitarte, $\mathrm{n}^{\circ}$ 22, 2000, pp. 5-8.

67 Antonio Trueba, Cielo con nubecillas...op. cit., pp. III-IV; Mari-Santa...op. cit., p. 43; El redentor moderno...op. cit., p. 17 y Cuentos del hogar...op. cit., pp. 379-380. Además, Javier Barrio Marro y Goio Bañales García, "Antonio de Trueba y su visión de Las Encartaciones”...op. cit., pp. 76-78 y Javier Pérez Núñez "La comunidad imaginada...op. cit., pp. 58-59. 
dado"68 o, en otras palabras, aceptar la situación social que a cada no le ha correspondido.

Pero para el autor vasco el trabajo no sólo es indispensable para el mantenimiento de una estructura social jerárquica, sino que también es un revulsivo para sofocar las convulsiones sociales, es "el redentor moderno". Aquí se encuentra el sentido de la novela del mismo título. En ella el protagonista es Eugenio Gendiaga, apóstol del trabajo. Este joven huérfano llega a Isgalde para descansar y meditar sobre su futuro, y se encuentra con un pueblo abandonado de la mano de Dios y donde reina la mayor de las anarquías; una especie de recreación de lo que habría ocurrido en el País Vasco de haberse implantado la revolución. Pues bien, para Eugenio Gendiaga se convierte en imperativo categórico redimir a este pueblo de la pobreza, del error y de la ignorancia. El verdadero calvario que le hacen sufrir los moradores con las trabas y obstáculos que le imponen, le ocasionan distintas caídas, que hacen que esté a punto de desfallecer. Pero la lectura de literatura instructiva y moralizadora, así como su profunda fe religiosa, le animan y dan fuerzas para seguir adelante. Así, se nos presenta al protagonista como el prototipo del "hombre católico" al que aspira el catolicismo conservador más ortodoxo69. Pues bien, al final, en el descubrimiento de unas tierras especiales para la fabricación de calizas hidráulicas se encuentra la clave para el despegue económico y el cambio social. Así, transformado el pueblo con numerosas fábricas y talleres artesanos, roturaciones y cultivos, con nuevas casas, calles y edificios públicos, el trabajo muda el talante y actitud de la gente, haciéndola más amable, educada y feliz. En definitiva, subraya Antonio Trueba: "Hubo un tiempo en que la fe religiosa bastaba para redimir a los pueblos; hoy la fe se ha debilitado tanto, que por sí sola no basta para tan santa obra; pero Dios suple su debilidad con un nuevo redentor, que es el trabajo"70.

Aunque en esta novela afirme que "la agricultura es el medio más permanente y eficaz de asegurar la subsistencia de los pueblos", Antonio Trueba, familiarizado como estaba con la importante actividad industrial de Las Encartaciones, la complementa con distintos talleres y establecimientos fabriles dedicados a los sectores pesquero y de la construcción. Pero, además, también están presentes en ésta y anteriores narraciones las actividades relacionadas con la mineria, la metalurgia e industria artesanal (ferrerias y martinetes), el transporte para la exportación y el ferrocarril. Así, de la misma manera que le ocurre a Juan Gorostiza, el marido de Mari Santa, que, tras la quiebra de su empresa comercial americana, levanta con su hijo una nueva ferreria; Eugenio Guendiaga, antes de involucrarse enteramente en Isgalde, había sido socio de una compañía minera de extracción de hierro de los montes de Triano ${ }^{71}$.

68 Antonio Trueba, El gabán y la chaqueta...op. cit., especialmente, pp. 272, 346, 378 y 454. También, Historia de dos almas...op. cit., p. 11.

69 María Cruz Romeo Mateo, "El otro género de la religión: la masculinidad católica en la España isabelina" Inmaculada Blasco Herranz (ed.), Mujeres, hombres y catolicismo en la España contemporánea. Nuevas visiones desde la historia, Tirant Humanidades, Valencia, 2018, pp. 84-88.

70 Antonio Trueba, El redentor moderno...op. cit., especialmente, pp. 226, 314-314 y 393. Para un estudio más profundo de esta novela nos remitimos a Montserrat Amores, "Entre la novela de idilio y la de tesis: A propósito de El Redentor Moderno (1875), de Antonio de Trueba", Crítica Hispánica, nº XXXIV, I, 2012, pp. 43-72.

71 Antonio Trueba, El redentor moderno...op. cit., pp. 16 y 119 y Mari-Santa...op. cit., p. 219. También Montserrat Amores, "Entre la novela de idilio y la de tesis...op. cit., p. 52 
Por lo tanto, el escritor vizcaíno asume que se logra un mayor bienestar con el desarrollo de la agricultura y la industria, pero le cuesta dejar un hueco para el turismo. Tiene dificultades porque el veraneo de forasteros a los balnearios minerales y maritimos vascos es modernísimo y, a su modo de ver, siendo dificil aventurar si los pueblos puedan ganar en concepto material, siempre pierden en el moral "porque el ejemplo del lujo, del ocio, del regalo, de la disipación, los desmoraliza y hace que hasta el más modesto quiera salir de su esfera". De manera diferente lo contempla El Correo Vascongado, que ve en la guerra carlista el único obstáculo al progreso económico de Vizcaya y por eso considera que, si "se apartaran completamente del campo de la lucha armada, sería en lo industrial un pequeño país de Gales, por el asombroso desarrollo que tomaria en estos momentos la industria del hierro, y como punto de recreo y residencia veraniega una segunda Suiza"72.

\section{ANTE LA ABOLICIÓN FORAL: LA RUPTURA CON LA MONARQUÍA.}

Para construir la biografia de Antonio Trueba resulta imprescindible recurrir a sus narraciones porque en algunas de ellas realiza cameos o aparece como el literato que era, casi siempre muy reconocido, admirado y querido por los protagonistas del relato ${ }^{73}$. En otras narraciones aprovecha para rememorar páginas de su vida, volviendo en distintos momentos sobre las que le habian producido una mayor impresión, eso sí, otorgándoles matices nuevos o visiones diferentes. Así, su percepción de la primera guerra carlista es más amable y condescendiente desde la última; como la visión de la primera emigración en Madrid resulta más entrañable y romántica contemplándola desde su segunda estancia $^{74}$. Pues bien, este cambio de perspectiva también se produce con relación a la realidad institucional y nacional española, generándose un cierto desapego, ya antes de la remodelación de los regímenes forales, con la propia revolución de 1868 y el cuestionamiento que de éstos se empieza a producir, sobre todo, a partir del estallido de la guerra.

Muy pronto Antonio Trueba se percata de ello, de la pérdida de atractivo del modelo foral vascongado y del desarrollo de una opinión liberal contraria a su subsistencia por su vinculación al carlismo y por considerarlo una rémora para la construcción de un auténtico Estado nacional75. Así, en 1872, en El gabán y la chaqueta recoge el malestar que a ciertos "hijos de Castilla" les produce que los vascongados prefieran sus libertades seculares a las para él subyugantes

72 Antonio Trueba, El redentor moderno...op. cit., pp. 86-89 y El Correo Vascongado, 19-041873. En este periódico se aborda la parálisis, como consecuencia de la guerra, de la explotación minera, del desarrollo industrial y de las actividades portuaria y ferroviaria (números del 29 y $30-$ 05-1873 y 20-06-1873). También se informa de la llegada de braceros castellanos, que en Las Encartaciones -según dice- "llaman maquetos, sin duda aludiendo al mao o morral que constituye su equipaje y que llevan a la espalda” (27-04-1873).

73 Antonio Trueba, Cielo con nubecillas...op. cit., pp. 148-150 y El redentor moderno...op. cit., pp. 372-376. En Antonio Trueba, Cuentos de madres e hijos...op. cit., pp. 268-269 manifiesta que es un literato vanidoso. Para esta "presencia del yo" Montserrat Amores García, "Antonio de Trueba y su obra literaria”...op. cit., pp. 125-129.

${ }^{74}$ Antonio Trueba, El redentor moderno...op. cit., pp. 10-11 y Madrid por fuera...op. cit., pp. 46 y 214-217.

75 Luis Castells, "La abolición de los Fueros vascos", Ayer, n 52, 2003, p. 132 y Fernando Molina Aparicio, La tierra del martirio...op. cit., pp. 149-151. 
reconocidas por la Gloriosa y propongan para que las acepten "declararlos completamente independientes y dueños de vivir y gobernarse por sí solos, y no tardaremos -subraya- en verlos acudir hambrientos de pan para el cuerpo y para la inteligencia, arrojarse humildes a los pies de Castilla, suplicándola que tenga misericordia de ellos y vuelva a tomarlos bajo su protección y amparo". El escritor vasco no admite ni éste ni cualquier otro planteamiento que pudiera poner en cuestión "la gloriosa y fecunda unidad de España terminada con la Edad Media", a la que tanto contribuyeron los vascos, sobre todo, cuando la unidad religiosa se había quebrado con la revolución. Pero tal supuesto sí le sirve para afirmar la singularidad de las Vascongadas y conferirles los elementos necesarios para ser un Estado, ya que, según él, gracias a la benéfica combinación de un pueblo virtuoso y orgulloso como el vasco y un acendrado régimen foral, podrian subsistir por sí solas, como había sido siempre, sin tener que "mendigar el pan de nadie"76.

Este es el punto de partida de la defensa de la foralidad contenido en las narraciones de Antonio Trueba. En lo fundamental sigue las pautas arbitradas en la época isabelina, pero intensifica su utilización ante el discurso antiforalista que crece fuera del País Vasco en distintos sectores liberales con la guerra carlista. Así, el escritor vizcaíno intenta contrarrestar la imagen difundida, que representa al pueblo vasco "como compuesto de fanáticos salvajes, refractarios a toda cultura y a todo sentimiento de virtud y justicia" 77 , resaltando el alto nivel de alfabetización y de instrucción primaria de las Vascongadas, que según las estadísticas era superior a la media nacional. También, "aunque no fuera la lengua que él aprendiera de los labios maternales", destaca el euskera y lo hace recurriendo al académico Joaquín Traggia, alguien nada sospechoso de parcialidad -recalca-, que lo define como "una lengua viva, nacional, madre y antiquísima, y no ceder en cultura, riqueza, energía y suavidad a ninguna de las conocidas". A partir de aquí, lo considera como "resto antiquísimo y venerable de la lengua ibérica", permitiéndole unificar y singularizar al País Vasco, ahondando en la idea de su exclusión de la dominación de las invasiones extranjeras de la península y afirmar así el mito de la independencia originaria. Pero, al margen de ello, en cuanto antigua lengua ibérica a la que, según él, pertenece el nombre de España y otros muchos topónimos, anima a su aprendizaje y estudio para profundizar en el conocimiento de la arqueología y lingüística españolas; tanto más cuanto distingue al euskera como una lengua particularmente indicada para la poesía y para expresar los afectos y los sentimientos, como para el narrador vizcaino evidencian los apreciados antiguos trovadores y los nuevos o bertsolaris.

De esta manera, el euskera para Antonio Trueba es ante todo una lengua familiar (la de amatxu y maitetxu) y, al igual que ocurre con la música (de txistu y

76 Antonio Trueba, El gabán y la chaqueta...op. cit., pp. 464-468. Este planteamiento de exclusión de las provincias vascongadas se retoma en el debate que, sobre los Fueros, se desarrolla tras la guerra (Ref. Alberto Ciaurriz Belzunegui, La abolición de los Fueros vascos...op. cit., vol. I, pp. 38 y 111). Y, después de la abolición foral, Antonio Trueba se suma al distanciamiento y a la valoración negativa de lo castellano (Ref. Coro Rubio Pobes, La identidad vasca en el siglo XIX...op. cit., pp.330-331.).

77 Para profundizar en esta descripción, recogida en Antonio Trueba, Mari-Santa...op. cit., p. 175, se puede seguir a Fernando Molina Aparicio, La tierra del martirio...op. cit., pp. 160-163 y 173. 
tamboril) y la danza78, se integra en la única cultura que él entiende, la tradicional, la de las tradiciones -valga la redundancia-, los buenos usos y costumbres, convencionalismos, hábitos, emociones, etc. Algo similar ocurre con el progreso porque, aunque considere que es ley de la naturaleza, siempre lo afronta a la manera burkeana respetando el pasado ${ }^{79}$. Por eso la respuesta que da a aquellos liberales que tildan a los vascos de "refractarios al progreso" es la única posible para él, la que tiene cabida en su universo mental de los cuatro grandes principios "Dios, patria, familia y trabajo". De tal forma es así, que lo considera el lema fraternal de las Vascongadas, que se adecua a Irurat-bat excluyendo normalmente el trabajo, que se subsume en los anteriores ${ }^{80}$.

Para Antonio Trueba esos presupuestos son los que hacen a los vascongados un pueblo verdaderamente virtuoso, ya que, además de religiosos, patriotas, amantes de la familia y laboriosos, son hospitalarios, generosos y caritativos, fieles a las buenas costumbres y tradiciones, leales, honrados y morigerados, emprendedores, perseverantes y diligentes, respetuosos con el orden y la autoridad, y con la propiedad y las jerarquías sociales, etc. Un pueblo ejemplar con unos orígenes remotos asentado en un medio físico bastante favorecido por la naturaleza y que, al mismo tiempo, según el escritor vizcaíno, cuenta con una constitución ancestral idónea e intangible a la mudanza de los tiempos.

Así, asumiendo una concepción histórico-tradicional de Constitución, Antonio Trueba asienta la legitimidad de la ordenación foral vizcaína (y vascongada) en el pasado: “(...) nos reunimos (...) en las juntas generales de Guernica, donde hace más de mil años nos gobernábamos libremente". Pero, además, esta codificación foral, para nuestro autor fuerista tradicional, se adapta a todas las circunstancias y momentos, sin necesidad de tener que realizar adecuación alguna: “(...) estas libertades, repetimos, no tienen nada que envidiar a las más amplias y cacareadas de los Códigos constitucionales modernos". De ahí que, como ya hemos observado, para los vascongados, según el narrador vizcaíno, apenas si significan algo los nuevos derechos reconocidos por la Gloriosa, "la palabra (...) más antigua y familiar en Vizcaya (...) es la palabra república" o "(...) el decano del federalismo español o, mejor dicho, del federalismo universal, es el pueblo vascongado". Posteriormente, en el diario La Paz, en el que participa, rizando el rizo, en el artículo firmado por un colaborador, tras proclamar que las instituciones de las Vascongadas son "las más libres que han

78 Antonio Trueba: El gabán y la chaqueta...op. cit., p. 121; Narraciones populares...op. cit., p. 204; Mari-Santa...op. cit., pp. 176 y 186; "Sumaria noticia de las provincias vascongadas" en Almanaque de La Ilustración para 1876 por Don Carlos Frontaura con la colaboración de escritores distinguidos, Imprenta, Estereotipia y Galvanoplastia de Aribau y C ${ }^{\text {a }}$, Madrid, 1875; El redentor moderno...op. cit., pp. 176, 186 y 191; Cuentos de madres e hijos, op. cit., pp. 150 y 254; y Madrid por fuera...op. cit., p. 130. Para revalorización del euskera por los fueristas Coro Rubio Pobes, La identidad vasca en el siglo XIX...op. cit., pp. 145-148.

79 Antonio Trueba, El redentor moderno...op. cit., p. 314.

80 Antonio Trueba, Cielo con nubecillas...op. cit., p. 188 y El redentor moderno...op. cit., p. 12 . De esta manera la leyenda Irurac-bat, que enlaza fraternalmente a las provincias hermanas vascongadas, no es sólo por la singularidad de la cultura foral que las aúna, sino también porque profesan unos mismos principios superiores. Al respecto, Coro Rubio Pobes, La identidad vasca en el siglo XIX...op. cit., pp. 39-41 y 51-53. 
conocido los hombres desde que el mundo es mundo", se señalará que sus mayores enemigos son los que habían hecho la revolución de septiembre ${ }^{81}$.

Por supuesto, adhiriéndose a ese aserto, para Antonio Trueba, "el espíritu democrático y de igualdad social reinan en las provincias vascongadas desde tiempo inmemorial". Esta afirmación muy repetida contrasta con su rechazo, ya subrayado, al principio de la soberanía nacional, al régimen representativo, al sufragio universal y a la intervención del pueblo en las instituciones públicas. De ahí que fuera contrario a la aplicación de estos principios a las Vascongadas y también a su adecuación, como era el proyecto de reforma del reglamento de elección de las instituciones forales vizcaínas de 1870, que planteaba la elección de los apoderados a las juntas generales en proporción a la población, y no orgánica municipal como hasta entonces, y la terminación con el sistema de insaculación para la elección de la diputación foral. Que esta propuesta no prosperara, no por su oposición, sitúa la concepción democrática del narrador vizcaíno en la verdadera realidad, la del sufragio censitario moderado, que es el imperante en la formación de las instituciones municipales y forales vizcaínas durante la época isabelina. Por lo tanto, como otros fueristas, tiene una visión de la democracia muy particular, más mítica que real y totalmente ajena a la cultura liberal-republicana que la define. Así, La Paz, periódico ideológicamente afín a nuestro autor, calificará a los Fueros como "leyes eminentemente democráticas, formadas por los mismos pueblos, anteriores y superiores a todo principio" y los considera "eternos", asentados en la "soberanía de la razón y de la naturaleza"

Pues bien, es en el anterior reinado donde el escritor vizcaíno sitúa su ideal. Así lo considera, por su inquebrantable fidelidad a Isabel II, porque la Monarquía constitucional doctrinaria que ella habia presidido coincidía completamente con su visión conservadora del Estado y la nación española, y también porque bajo sus auspicios habian persistido y se habian reafirmado los regimenes forales, algo que como buen fuerista no puede por menos que satisfacerle plenamente. De ahí que el diario del que fue principal redactor Antonio Trueba, El Correo Vascongado, estimara que desde el convenio de Vergara hasta la revolución de 1868 el País Vasco "había gozado de una paz octaviana", no había habido "ataque ninguno importante en su ley política, ni en sus intereses, ni en lo que es de más valor, en sus creencias religiosas" y había disfrutado "de un bienestar general y de un desarrollo de la riqueza que no había visto (...) en época alguna". En definitiva, concluye: el reinado isabelino había sido "el más fecundo y glorioso de la historia de España"83.

81 Antonio Trueba, El gabán y la chaqueta...op. cit., pp. 69-71; Narraciones populares...op. cit., p. 47; y "Sumaria noticia...op. cit. Además, El Correo Vascongado, 18 y 22-04-1873 y 11-06-1873; La Paz, 1-06-1876 (cit. Alberto Ciaurriz Belzunegui, La abolición de los Fueros vascos...op. cit., vol. II, p. 241) y Javier Pérez Núñez, "La comunidad imaginada...op. cit., p. 66-67 y José María Portillo Valdés, El sueño criollo...op. cit., pp. 197-199.

82 Antonio Trueba, El gabán y la chaqueta...op. cit., p. 215; "Sumaria noticia...op. cit. Y Cuentos del hogar...op. cit., pp. 395-396. Además, La Paz, 14-06-1876 y 30-06-1876 (cit. Alberto Ciaurriz Belzunegui, La abolición de los Fueros vascos...op. cit., vol. III, p. 59 y vol. III, p. 159); Fernando Molina Aparicio, La tierra del martirio...op. cit., pp. 94-95; Mikel Urquijo Goitia, Liberales $y$ carlistas...op. cit., pp. 117-126 y Mercedes Vázquez de Prada, Negociaciones sobre los Fueros entre Vizcaya y el poder central, 1839-1877, Caja de Ahorros Vizcaína, Bilbao, 1984, pp. 282-285.

83 Editoriales (s.f.) de El Correo Vascongado, 26 y 29-04-1873. También Antonio Trueba, "Sumaria noticia...op. cit. 
Nuestro autor, que coincide en términos generales con este pensamiento, representa uno de los más claros ejemplos de fidelidades compartidas, la española y la vasca (principalmente la vizcaína), características del fuerismo. Pues bien, además de asumir este doble patriotismo, convierte el alto grado de legitimidad y de estabilidad social alcanzados por los ordenamientos vascongados durante la época isabelina en unanimidad foral sin discrepancias ideológicas: "En las Provincias Vascongadas todos son fueristas, cualesquiera que sean sus opiniones politicas, su vecindad, su ilustración y su riqueza; (...) al visitar el rey Don Alfonso Bilbao, entre las primeras aclamaciones que ha oído y las primeras inscripciones que ha leido en los arcos triunfales con que se le recibía, figuraba la de "iVivan los Fueros!" 84 . A partir de aqui, frente aquellos liberales que presentan a estas singularidades como un obstáculo para el progreso, las sigue significando como un modelo civilizatorio, que pueden seguir las provincias españolas más atrasadas: “(...) viven tan desahogadas, prósperas y alegres, que envidian su dicha los muchos forasteros cuya visita reciben reunidas a la sombra de un árbol"; “(...) las Provincias Vascongadas son la tierra de promisión para los de otras más infortunadas". Por eso, desde esta instantánea tan deslumbrante, la restauración anhelada por Antonio Trueba, si no propone el retorno de Isabel II (como ya hemos señalado), sí a la cultura y al modelo político-social moderado de su reinado ${ }^{85}$; eso sí, una vez superados el sexenio revolucionario y la guerra carlista, considerados, por lo menos la segunda, un simple paréntesis luctuoso.

No lo contemplan de esta manera algunos liberales foráneos, que ven este conflicto como un verdadero punto de inflexión. Así, desde una estrecha identificación entre los vascongados, los Fueros y el carlismo, perciben la guerra civil, siguiendo la lógica del fuerismo, como un incumplimiento del convenio de Vergara y por eso, para ellos, a su terminación no cabe otra salida que la de la abolición foral ${ }^{86}$. Tal planteamiento encoleriza a Antonio Trueba hasta el punto de proceder a revisar la evolución histórica desde la ley confirmatoria de los Fueros de 25 de octubre de 1839, aún a costa de generar una importante contradicción con su anterior pensamiento. De tal forma que, siguiendo muy de cerca al fuerista tradicionalista Arístides de Artiñano, abre la espita hacia una desnacionalización española y empieza a considerar que, desde el mismo

\footnotetext{
84 Antonio Trueba, Narraciones populares...op. cit., p. 47-48 y Cuentos del hogar...op. cit., p. 357 (donde se encuentra la cita). También, El Correo Vascongado, 26-04-1873. Para el doble patriotismo: Antonio Elorza, Ideologias del nacionalismo vasco, 1876-1937 (De los "euskaros" a Jagi Jagi), L. Haranburu Editor, San Sebastián, 1978, p. 21; Jon Juaristi, El linaje de Aitor...op. cit., pp. 40-41; María Cruz Mina Apat, "Historia y política...op. cit., pp. 278-279; Fernando Molina Aparicio, La tierra del martirio...op. cit., pp. 44, 102 y 104-105; y Coro Rubio Pobes, La identidad vasca en el siglo XIX...op.cit., pp. 153-168 y 328-329 (particularmente referidas a Antonio Trueba).

85 Antonio Trueba, Cielo con nubecillas...op. cit., p. 188; El gabán y la chaqueta...op. cit., p. 69; Narraciones populares...op. cit., p. 48; y Cuentos del hogar...op. cit, pp. 407-408. Para la vasconización de España: José María Sánchez-Prieto, El imaginario vasco. Representaciones de una conciencia histórica, nacional y politica en el escenario europeo 1833-1876, Eiunsa, Barcelona, 1993, pp. 765-817 y 908-909 y Fernando Molina Aparicio, La tierra del martirio...op. cit., pp. 262266.

86 Javier Corcuera Atienza, Orígenes, ideologia y organización del nacionalismo vasco, 18761904, Siglo XXI, Madrid,1979, pp. 81-82; Fernando Molina Aparicio, La tierra del martirio...op. cit., pp. 174-177; y Coro Rubio Pobes, “¿Qué fue del oasis foral?...op. cit., p. 88.
} 
momento de la aprobación de esa norma, aún a pesar de la tranquilidad y sumisión del pueblo vascongado, que habia sido ajeno al mal ejemplo ocasionado por las frecuentes rebeliones producidas allende el Ebro (incluidas carlistas), las instituciones centrales la habían vulnerado. Así, "con el pretexto de la unidad constitucional" -señala en Mari Santa- "se había ido destrozando el código de las libertades vascongadas (...) sustituyendo casi toda la legislación foral con la general del reino".

Este mismo argumento lo reitera en su "Sumaria noticia de las provincias vascongadas" y en las anotaciones que realiza en el artículo que traduce sobre él como literato del francés de Lucien Louis-Lande: "Los Fueros -subraya- no han influido para nada en la rebelión carlista, a la que en todo caso habrán favorecido los contrafueros, que cuando (...) empezó la rebelión en las Provincias Vascongadas (...) apenas quedaba del Código foral más que la portada" 87 .

De esta manera comienza la refutación del narrador vasco al citado autor, claramente adherido al posicionamiento de la mayoria de la prensa liberal madrileña que, condenando la ingratitud de esas provincias, reclama la abolición de los Fueros con la terminación de la guerra. También, Lucien Louis-Lande avala dicha operación quirúrgica para eliminar lo que para él era el germen de rebeldia vasco, que había generado tantos costes a las arcas del Estado y tantas pérdidas humanas; $\mathrm{y}$, además, al parecer influido por el modelo unitario $\mathrm{y}$ centralizador galo, igualmente la respalda para que dichas provincias, sometidas a la ley común, se incorporen definitivamente a la nación española. Antonio Trueba discrepa tajantemente de tales planteamientos, afirma no sólo que los Fueros no habian tenido nada que ver con la guerra, sino que ésta -como se recogerá en las páginas de La Paz- se había producido a pesar de los Fueros, que habían sido un importante obstáculo, y, por eso, su abolición le parece una flagrante injusticia. De esta manera, aunque rechace el calificativo de rebeldes conferido a los vascos -arguyendo que las autoridades legítimas provinciales habian sido fieles al poder central y la mayoría de los seguidores del pretendiente habian sido forzosos y no voluntarios-, sin embargo, afirma que la supresión de aquellos "equivaldría a enarbolar una constante bandera de rebelión a que se acogieran todos los rebeldes, blancos o negros".

Al margen de esta presión coactiva, que entonces resultaba totalmente contraproducente, recurre a otro tipo de argumentos. En primer término, a uno elitista muy conservador, que desenmascara su tan traída defensa de la democracia vasca. Para él la mayor suma de individuos no constituye la mayoría, sino la mayor suma de riqueza, ilustración y sacrificios. En este concepto, la inmensa mayoria de los vascos, que residen en sus capitales y principales poblaciones, habian sido leales, y no sólo eso, además, eran los que más tienen que perder con la supresión de los regimenes forales. Por eso, su abolición, para Antonio Trueba, supone castigar a los leales y dejar impunes a los sublevados, que apenas si tendrían quebranto alguno con la abolición.

En segundo término, porque -afirma nuestro autor- se puede calificar a la guerra carlista de criminal y por ello castigar al País Vasco, pero no más que al

87Antonio Trueba, Mari-Santa...op. cit., p. 192; y, también, El gabán y la chaqueta...op. cit., p. 287, "Sumaria noticia...op. cit. y Cuentos del hogar...op. cit., pp. 172 y 395. Para el pensamiento de Arístides de Artiñano en este aspecto: Juan José Solozábal, El primer nacionalismo vasco, Industrialismo y conciencia nacional, L. Haranburu Editor, San Sebastián, 1979, pp.298-302. 
resto de las provincias, que durante treinta años habian sido un "hervidero continuo de rebeliones, coronadas, primero, con el destronamiento de la reina Isabel II" y, después, con seis convulsos años, que no podian considerarse "peccata minuta y [menos aún] gloriosos".

En tercer término, porque conviniendo, como hace el escritor vizcaíno, en que las libertades vascongadas no son privilegios sino derechos propios, resultan ser "tan legitimas como podian serlo las de los demás españoles, y el reconocerlas y respetarlas no es gracia, que es sólo estricta justicia". Esta equiparación y trayectoria paralela de constituciones, las vascongadas y la española, son la expresión de la afirmación de la identidad colectiva vascongada, pero, siguiendo la doctrina fuerista conservadora subrayada por José María Portillo, para afirmar a las provincias como cuerpo político y mantener el vínculo con España a través de una reanudación del pacto con la corona. De ahí que Antonio Trueba, desde una visión de la monarquía constitucional muy cercana a la tradicional, pusiera el destino de los Fueros en manos de Alfonso XII ${ }^{88}$.

Así lo piensa a su regreso definitivo a Bilbao de Madrid en abril de 1876, después de despedirse de este monarca con un poema ("Al que regresa, el que parte", recogido en el Álbum Poético) en el que, recordando a su "magnánima, sabia y dulce" madre, le agradecía la pacificación lograda. Pues bien, no pudo tener una mejor recepción, ya que, en las juntas generales extraordinarias celebradas en dicho mes, no sólo recuperó el puesto de archivero y cronista de Vizcaya, sino que, además, por la lealtad y servicios prestados, fue elevado a la categoría de padre de provincia. Este nombramiento entonces adquiere mucho valor porque, en el proceso de adecuación de los regímenes forales abierto por el gobierno de Antonio Cánovas, los padres de provincia iban a participar en las decisiones politicas fundamentales de la provincia, a través del regimiento general y la junta permanente extraordinaria, convocados frecuentemente. A esta involucración de Antonio Trueba en la esfera pública, en la que siempre se decanta por los planteamientos y posiciones fueristas intransigentes, se sumó una elevación de su consideración, dejando de ser el escritor de cuentos (Antón, el de los cantares) para pasar a ser un asesor foral. Así, al tiempo que su Bosquejo de la organización social de Vizcaya se convirtió en un referente de la defensa de los fueristas, se recurrió a él para la elaboración de las dos principales exposiciones de las diputaciones vascongadas "contra la abolición de los Fueros", las elevadas a las Cortes el 16 de junio y al rey Alfonso XII en el mes siguiente de 1876.

Durante este proceso, que después resumió en el artículo "Los tristes días", su labor política no se limitó a la redacción de esos dos textos, en los que se recogen ideas contempladas en su obra de ficción. También colaboró en periódicos de la órbita fuerista como El Noticiero Bilbaíno y, sobre todo, La Paz. Siguió publicando artículos en la Ilustración Española y Americana, pero su actividad literaria se restringió al

88 Antonio Trueba, Cuentos del hogar...op. cit., pp. 402-409; La Paz, 15-05-1876 (cit. Alberto Ciaurriz Belzunegui, La abolición de los Fueros vascos...op. cit., vol. II, p. 99). En Alberto Ciaurriz Belzunegui, La abolición de los Fueros vascos...op. cit., vol. I, Fernando Molina Aparicio, La tierra del martirio...op. cit., pp. 249-253 y Mercedes Vázquez de Prada, Negociaciones sobre los Fueros...op. cit., pp. 299-302 y 309-313 se puede corroborar lo que dice Louis-Lande sobre la prensa madrileña y en José María Portillo Valdés, El sueño criollo...op. cit., pp. 198-204 el doble constitucionalismo. 
máximo, limitándose a una recopilación de narraciones cortas, Cuentos de madres $e$ hijos (1878) y a la reedición de Alrededor de Madrid como Madrid por fuera (1878)89.

Antonio Trueba escribió las citadas exposiciones una vez que no prosperaron las actuaciones de las autoridades forales para frenar la propuesta de inclusión en las contribuciones generales (fiscal y militar) y de reforma de las instituciones de las Vascongadas. Fracasaron, primero, las negociaciones entre los comisionados de estas provincias y el Gobierno del artífice de la Restauración y, seguidamente, las intervenciones de los senadores y diputados fueristas igualmente de las Vascongadas para impedir que fuera adelante el proyecto de ley que contenía la señalada propuesta. Estas acciones estuvieron muy ancladas en el pasado isabelino tanto en cuanto a la estrategia seguida, fundada ante todo en la politica de dar largas, como en el contenido de los argumentos utilizados. Estos se asentaron en la desvinculación de los Fueros de la guerra carlista y la especial salvaguarda que para ellos contaban, la vigente ley de 25 de octubre de 1839, que, calificada de paccionada, complementaria o acta adicional, los integraba en el régimen constitucional común y en derecho público español. Este "fundamento moderno de los Fueros", que exigía respetar su esencia en cualquier propuesta de modificación, estaba acompañado del recurso a los mitos forales tradicionales (vasco-iberismo, independencia originaria, incorporación pactada...), a la consideración de los Fueros como constitución interna de los vascos (modo de ser, civilización, cultura propia, patrimonio, libertades más antiguas....), a la defensa del modelo descentralizado y pluralista como freno al despotismo del poder central y, sobre todo, al acendrado patriotismo y adhesión a la nación española de los vascongados, a lo largo de la historia y ese momento, sobre todo, de los liberales leales en quienes, como ya habia destacado Antonio Trueba, residía la riqueza del país.

Este discurso era totalmente distante al expuesto por la mayoría de los representantes en Cortes, que demandaban la abolición foral por una cuestión de equidad y justicia, y para afirmar el Estado de Derecho, así como la igualdad y la unidad jurídica. Era ajeno porque estaba orientado principalmente a Antonio Cánovas, como conocedor y admirador de los regímenes forales, pero fundamentalmente como presidente del Gobierno. Lo que se pretendía era que la cuestión foral, como había ocurrido en la época isabelina, se dirimiera en ámbito ejecutivo con el monarca a la cabeza. De ahí, que, un tanto extemporáneamente, la segunda de las exposiciones se dirigiera a Alfonso XII para que no sancionara la célebre ley de 21 de julio de $1876^{90}$.

Tanto esta exposición como la anterior remitida a las Cortes siguen el ideario y la linea argumental ya expuestas del fuerismo moderado, pero Antonio Trueba lo hace a partir de una especie de sintesis, eso si algo embarullada, de las aportaciones realizadas en su obra literaria. Al igual que los comisionados y representantes a Cortes de las Vascongadas, el eje de su relato gira en torno a la ley de 25 de octubre de 1839, "fundamento legal y solemne del derecho foral". En

89 Ricardo Becerro de Bengoa, Trueba...op. cit., pp. 37-49; José Antonio Ereño Altuna, Antonio de Trueba...op. cit., pp. 50-55; Jon Juaristi, El linaje de Aitor...op. cit., pp. 136 y156; Mercedes Vázquez de Prada, Negociaciones sobre los Fueros...op. cit., pp. 318, 352 y 388.

90 Fermín Lasala y Collado, Última etapa de la unidad nacional. Los fueros Vascongados en 1876, Real Academia de Ciencias Morales y Politicas, Madrid, 1924, vol. II, pp. 9-84; Javier Corcuera Atienza, Orígenes, ideología...op. cit., pp. 83-85; María Cruz Mina Apat, "Historia y politica...op. cit., pp. 293-309; Mercedes Vázquez de Prada, Negociaciones sobre los Fueros...op. cit, pp. 294-351; y Antonio Trueba, "Los dias tristes", El Noticiero Bilbaino, 4-05-1885. 
primer lugar, asienta lo que denomina antecedentes histórico-legales, que fundamentalmente son los grandes mitos forales, deteniéndose en el de la independencia originaria, que avala con los elementos étnicos del "idioma, las leyes, las costumbres y (...) la raza vascongada", y el de la incorporación pactada a la Corona de Castilla, subrayando el carácter "libre, voluntario y condicionado al respeto y amparo de los Fueros". Pues bien, para el narrador vizcaíno, aquella ley no es más que un reconocimiento y confirmación de este pacto con la Corona, sancionado por sus sucesivos titulares.

En segundo término, interpreta esta norma de acuerdo con lo que en su momento entendieron los moderados, de manera que queda reducida solo a la confirmación foral en el sentido más amplio. Es así porque para él los Fueros abrazan "todas las existencias legislativas (...) todo lo que constituye el sistema foral", es decir, viene a ser como el régimen político estatal un sistema completo de gobierno o como subraya de manera muy expresiva el periódico afín La Paz "son perfectos derechos, legislación propia del País Vascongado, autonomía secular que nunca renunció" 91 . También se concluye en esa simple confirmación si la cláusula de la unidad constitucional la limita, como hace Antonio Trueba siguiendo al moderado Lorenzo Arrázola, a la existencia de los grandes vínculos de un rey constitucional y una representación nacional común. Obviamente, desde esta óptica, no se produce contradicción alguna entre la Constitución y los Fueros, y, por lo tanto, no resulta necesario realizar modificación alguna; menos aún, cuando estima que la ocasión carece de la oportunidad, que también aparece -recuerda- preceptuada en la misma ley.

No es el momento más a propósito para Antonio Trueba porque, después de ocho años de continuas perturbaciones que habian arrumbado con un "trono secular" y "la unidad religiosa" y terminado en "una sangrienta guerra civil," se necesita paz y descanso. Por eso el proyecto presentado, que para él significa la "abolición de los Fueros", supone -como ya había esbozado previamente- un trato discriminatorio con otras provincias y un castigo injusto y desmesurado, primeramente, para los liberales vascongados $\mathrm{y}$, después, al conjunto de sus poblaciones. Lo contempla así, distanciándose de lo anteriormente señalado, porque, al margen de que para él fuera inexistente la relación causal entre los Fueros y la guerra carlista, con la supresión de las libertades e instituciones forales la prosperidad alcanzada desaparecería. Así, gracias a ellas, recuperando páginas del Bosquejo de la organización social de Vizcaya, los vascongados habían logrado dominar el inhóspito medio físico y constituir "rústicas caserias, donde no hay más atractivo que el santo y dulce calor de la familia que las anima y las alegra". Además, la eliminación de los Fueros, que para el conservador Antonio Trueba son, a la manera burkeana, una especie de sagrada herencia "recibida de nuestros padres y ansiamos transmitir a nuestros hijos", supone poner fin al último vestigio de las antiguas libertades españolas, tal y como había significado en el debate en el Congreso el egregio Emilio Castelar. Por eso a La Paz le parece mentira que se quieran destruir unas leyes "que por los siglos de los siglos han

91 La Paz, 26-05-1876 y también 6-06-1876 (cit. Alberto Ciaurriz Belzunegui, La abolición de los Fueros vascos...op. cit., vol. II, pp. 195-196 у 265). 
representado la genuina nacionalidad española en toda su pureza y sin mezcla de extranjerismo"92.

De aquí que, como ya sabemos, lo que, según el escritor vizcaíno, caracteriza a los vascongados, además de su amor a los Fueros, al trabajo y a la familia, es su acendrado patriotismo o, como dice aquí, su "adhesión a la nacionalidad española". Así, siguiendo lo apuntado en 1875 "Sumaria noticia de las provincias vascongadas", no sólo los presenta como los primeros españoles, incluso antes de la formación de la Monarquía española, sino que les hace ocupar "un puesto preeminente en todas las páginas de la historia nacional, así en las se refieren a la larga y gloriosa lucha de la reconquista, como en las que se refieren al descubrimiento y colonización de nuevos continentes". Lo que quiere decir con ello, y con datos más pormenorizados ${ }^{93}$, es que las Vascongadas a su manera siempre han contribuido con hombres y dinero.

El patriotismo y también la lealtad constituyen para nuestro narrador otra seña de identidad de los vascongados. Lo ilustra con el reinado de Isabel II, que ahora pinta con colores tan resplandecientes que hace que para él España prosperara entonces hasta el nivel de "las naciones de primer orden". Esto no obsta para que, durante este tiempo, con la excepción de las Vascongadas, "patriótico ejemplo de paz, de lealtad y de obediencia", el resto del Estado hubiera sido "un hervidero casi continuo de rebeliones", que culmina con el destronamiento de "la augusta y bondadosa" monarca.

Pues bien, porque quizá intuyera que no iba a poder ser tramitada la representación a Alfonso XII, como asî ocurrió, introdujo en ella algunas apreciaciones que pueden ubicarse en la senda ya abierta de la desnacionalización española. La primera de ella se refiere a la consecuencia que extrae de la oposición generalizada desarrollada en la opinión pública española contra las Vascongadas, a las que negaba "hasta la virtud de patriotismo", ya que según Antonio Trueba podría despertar en éstas "el desamor del opresor que naturalmente se despierta en el corazón oprimido". La segunda de las apreciaciones era aquella con la que en alguna medida viene a estigmatizar al rey si sancionaba el proyecto de ley sobre los Fueros vascongados, porque, subraya, entonces pasaría a la historia como el monarca "que derribó el santo árbol simbólico de las libertades vascongadas, amparado y bendecido por sus augustos predecesores"94.

92 La Paz, 6-06-1876 (cit. Alberto Ciaurriz Belzunegui, La abolición de los Fueros vascos...op. cit., vol. II., p. 253).

93 Así, en la exposición a las Cortes señala: “(...) En 18 de abril de 1595 se expidió una Real Provisión, en la que se hizo constar que el Señorio de Vizcaya había derramado tanta sangre por mar y por tierra en servicio de S.M., que había en él más de ¡diez mil viudas! —En el período de 1793 a 1825 el mismo Señorío había contribuido voluntariamente, y con arreglo a los Fueros, al alivio de las necesidades del Estado, con la suma de ciento veinte y ocho millones de reales (...)". También Antonio Trueba, "Sumaria noticia...op. cit. y Coro Rubio Pobes, La identidad vasca en el siglo XIX...op. cit., pp.141-144.

94 Antonio Trueba, Datos para la historia de Vizcaya, Tipografia de Antonio Villamarín, Lugo, 1900, pp. 205-238 y Joseba Agirreazkuenaga Zigorraga (Ed.), La articulación politico-institucional de Vasconia. Actas de las Conferencias firmadas por los representantes de Álava, Bizkaia y Gipuzkoa, y eventualmente Navarra (1775-1936), Bilbao Diputaciones Forales de Bizkaia, Gipuzkoa y Álaba, 1995, vol. II, pp. 766-783. Complementarias: Fermín Lasala y Collado, Última etapa de la unidad nacional...op. cit., vol. II, p. 141; Gregorio Monreal Zia, "La ley abolitoria de los 
Alfonso XII lo sancionó y la ley de 21 de julio entró en vigor dos dias después con su publicación en la Gaceta de Madrid. Parece que produjo en las Vascongadas un sentimiento generalizado de incomprensión y frustración. Pues bien, todo indica que fue un sentimiento alimentado tanto por las impresiones que le trasladaron las autoridades forales dominadas por los fueristas intransigentes como por su propia actuación fundada en la tajante negativa a colaborar directa o indirectamente en la aplicación de la citada norma por considerarla derogatoria de los Fueros ${ }^{95}$. Así ocurrió en Vizcaya bajo el liderazgo de Fidel Sagarminaga, diputado general y principal catalizador del fuerismo intransigente en esta provincia, del que Antonio Trueba era un fiel seguidor. Por eso se sumó a las iniciativas lideradas por aquel, que sirvieron para formar las mayorias que reafirmaron la resistencia a la ley y rechazaron cualquier negociación. Ante tal actitud, el Gobierno, que tenía la firme voluntad de aplicar la ley, respaldado como estaba en las Vascongadas con el mantenimiento de la suspensión de las garantías constitucionales, la censura de prensa y la presencia militar en lugares neurálgicos, acabó por disolver las instituciones forales, primero, en mayo de 1877 en Vizcaya y, después, en noviembre en Álava y Guipúzcoa. De esta manera se puso fin a la autonomía política, que tan alto grado había alcanzado en el reinado isabelino, pero se pudieron mantener las autonomías fiscal y administrativa por medio de primer concierto económico de 1878, resultado de las negociaciones entre las nuevas Diputaciones provinciales de las Vascongadas, bajo las riendas de los fueristas transigentes, y el ejecutivo de Antonio Cánovas ${ }^{96}$.

"En los tristes dias", que recogía la actuación de las Diputaciones forales durante el bienio 1876-1877, Antonio Trueba concluía señalando que "el pueblo vascongado bajo el peso de la ley abolitoria (...) SE QUEBRÓ, PERO NO SE DOBLÓ”. Pues bien, él sí sufrió un importante quebranto, al desmoronarse uno de los pilares fundamentales de su pensamiento, la Monarquía. Esta institución, desde su perspectiva conservadora, clave para lograr la unidad política y religiosa, y también para la definición de España como Estado nacional, quedaria definitivamente silenciada. De esta manera, a partir de este momento se produjo una ruptura de sus relaciones con la Casa Real, incluidas las mantenidas con su querida y apreciada Isabel II, a la que desestimó respetuosamente una invitación para acudir a su residencia. Por supuesto, con el titular de la Corona, a pesar de haber sido alfonsino, su distanciamiento fue bastante mayor y menos complaciente. Así, en su poema La Musa indignada al maldecir a los autores de aquella ley y tildar de tiranos (...más llegaron al pie de aquel árbol/tiranos impíos/y asestaron sus hachas/al tronco secular, respetado y bendito...), no parece que quedara excluido el primer rey de la Restauración ${ }^{97}$. Por eso en su "Carta Vascongada", prólogo a Cartas

Fueros de 21 de julio de 1876 (Antecedentes y paso por el Congreso), Iura Vasconiae, $\mathrm{n}^{\circ} 10,2013$, pp. 135-137 y 187-188; Antonio Trueba, "Los dias tristes", El Noticiero Bilbaino, 4-05-1885; y Mercedes Vázquez de Prada, Negociaciones sobre los Fueros...op. cit., pp. 352-353.

95 Javier Corcuera Atienza, Origenes, ideología...op. cit., pp. 105-106; Coro Rubio Pobes, La identidad vasca en el siglo XIX...op. cit., pp. 116-117 y 169-174; y Juan José Solozábal, El primer nacionalismo vasco... op. cit., pp. 292-293.

96 Fermín Lasala y Collado, Última etapa de la unidad nacional...op. cit., vol. II, p. 161 y 175176; Javier Corcuera Atienza, Orígenes, ideología...op. cit., pp. 85-91; Mercedes Vázquez de Prada, Negociaciones sobre los Fueros...op. cit., pp. 354-395; Luis Castells, "La abolición de los Fueros vascos"...op. cit., pp. 137-141 y 144-147 y Antonio Trueba, "Los días tristes," El Noticiero Bilbaíno, 11-05-1885.

97 Aunque en una nota señala que no tiene ninguna relación, su explicación no tiene sentido alguno: "Para evitar cavilosidades, debe prevenir el autor de estos versos que el tirano a quien en ellos se alude es la guerra civil, que, conculcando todas las leyes y libertades, constituye el más 
irlandesas y húngaras de José María Lizana en el que viene a recuperar de forma sintética las exposiciones redactadas en 1876, calificaba a Alfonso XII, de acuerdo con lo vaticinado en éstas, como el "primer monarca de Castilla que no reconoció y sancionó aquel derecho" (se refiere a los Fueros respetados y amparados, según el escritor vizcaino, desde el pacto de incorporación) ${ }^{98}$.

Antonio Trueba tampoco se doblegó y se mantuvo fiel al ideario fuerista conservador. Así, se sumó a las organizaciones patrocinadas por Fidel Sagarminaga: primero, la Unión Vasco Navarra; y, después, la Sociedad Euskalerria, que, como herederas del fuerismo tradicional, continuaban con el lema "Dios y Fueros" (Jaungoikoak eta Foruak) y reivindicaban la derogación de la ley de 21 de julio de 1876 y restauración integra de los regímenes forales. Esta debía ser la única bandera y, para ello, planteaban el abstencionismo de los problemas del resto del Estado y, superando las antiguas fidelidades partidistas, la unión de los vascos bajo una misma conciencia nacional. Así, siguiendo planteamientos ya apuntados por $L a P a Z^{99}$, daban entrada a la idea de nacionalidad como identidad colectiva que, viniendo a actualizar la doctrina pactista, no resultaba contradictoria con un Estado y nación española que se organizara territorialmente de manera descentralizada o reconociera la autonomía foral vasca. Pues bien, este pensamiento, junto a la recuperación de la relectura histórica desde una perspectiva desnacionalizadora, lo asume Antonio Trueba en el prólogo citado, en el que viene a señalar que las luchas nacionales de los irlandeses y húngaros descritas por su fraternal amigo, podian "ofrecer al pueblo vascongado modelos de amor a las libertades patrias, y de constancia, de abnegación y de perseverancia en su defensa ${ }^{100}$."

\section{CONCLUSIONES.}

Antonio Trueba, afamado literato de la época isabelina, a la par que periodista, archivero y cronista de Vizcaya, estuvo estrechamente ligado al fuerismo o moderantismo vasco. De esta manera asumió la doctrina

abominable de los tiranos" (Ref. El libro de los recuerdos, Librería de Antonio Romero, Madrid,1910., p. 66).

98 Antonio Ttueba, "Los dias tristes," El Noticiero Bilbaino, 11-05-1885; 1910, pp. 66-71; y "Carta vascongada” en José María Lizana, Cartas irlandesas y húngaras, viuda de Delmas, Bilbao, 1881, p. VIII. Para su relación con la Monarquía: Montserrat Amores García, Antonio de Trueba...op. cit., p. 43; Ricardo Becerro de Bengoa, Trueba...op. cit., p. 37; y José Antonio Ereño Altuna, Antonio de Trueba...op. cit., p. 50.

99 En el número del 15-05-1876 se publicó el artículo "El país pintado por sí mismo", que generó un importante escándalo en la prensa liberal porque, entre otras cosas, señalaba: “(...) todos sin excepción somos fueristas, como todos los que han nacido en la península ibérica son españoles, a pesar de no tener la misma opinión politica; y somos fueristas porque para nosotros los Fueros son algo más que una opinión política, una nacionalidad (...)" (cit. Alberto Ciaurriz Belzunegui, La abolición de los Fueros vascos...op. cit, vol. II, p. 101).

100Antonio Trueba, "Carta vascongada"...op. cit., 1881, p. XII; Antonio Elorza, Ideologías del nacionalismo vasco...op. cit., pp. 76-86; Javier Corcuera Atienza, Orígenes, ideología...op. cit., pp. 122-130 y 155-161; José María Portillo Valdés, El sueño criollo...op. cit., pp. 221-223; y Coro Rubio Pobes, La identidad vasca en el siglo XIX...op. cit., pp. 67-69, 276-277 y 470.

Antonio Trueba hasta su muerte, acaecida en Bilbao el 10 de marzo de 1889, ocupó el puesto de archivero y cronista de Vizcaya, pero, sobre todo, siguió dedicándose a la actividad literaria, dirigiendo la sección literaria de El Noticiero Bilbaino, colaborando en distintos diarios fueristas y escribiendo cuentos y poemas, recopilados en libros como Nuevos cuentos populares (1880), De flor en flor (1882), Cuentos populares de Vizcaya (1897) y El libro de los recuerdos (1910). 
característica de éste del doble patriotismo español y vasco, que suponía compartir las dos identidades (si se quiere tres, para dejar un hueco a la provincial vizcaína), además estrechamente interrelacionadas, ya que se consideraba a la vasca la genuina española. Igualmente, significaba concordar en un modelo constitucional muy conservador, que permitía mantener un orden político, social, cultural y religioso muy cercano al tradicional. Esto facilitó que, bajo la Monarquía constitucional doctrinaria y católica de Isabel II, no sólo pudieran persistir los regímenes forales vascos, sino que alcanzaran su pleno desarrollo. Así, el tiempo, abierto desde la ley confirmatoria de los Fueros de 25 de octubre de 1839 hasta el destronamiento de la reina, se contempla como una etapa de tranquilidad y prosperidad, en la que para Antonio Trueba, gracias a la íntima conjunción entre un pueblo virtuoso y ejemplar, como el vasco, y una constitución ancestral idónea e intangible a la mudanza de los tiempos, como los Fueros, Vizcaya (y por extensión el País Vasco) se convierte en un modelo civilizatorio tanto a nivel industrial como medioambiental. De ahí que El Correo Vascongado presentara a esta provincia, a la vez, como "un pequeño país de Gales" y "una segunda Suiza".

Ya, en la recta final de la Monarquía isabelina, se empezaron al producir fisuras en el modelo conservador, lo que acabó ocasionando que sectores importantes de los moderados y de los fueristas se trasladaran a la órbita del tradicionalismo. A la misma Antonio Trueba, que había estado cercano a la tendencia del neocatolicismo, no tuvo problema alguno en sumarse y en participar en la articulación del foral-catolicismo. Desde esta posición más reaccionaria la aprehensión de la Revolución gloriosa de 1868 y, después, del sexenio democrático en su conjunto no podía ser más apocalíptica: para los adheridos a esa tendencia no sólo se destruían los grandes principios de la sociedad, sino la base y el pilar fundamental de todos ellos, la religión, se veía arrumbada con la aprobación de la libertad de cultos. Así, para el escritor vizcaíno desaparecía la seña de identidad que durante siglos había definido a España y los españoles e imperaba la anarquía más espantosa. El País Vasco era la excepción porque, gracias al régimen foral y a sus dirigentes (tradicionalistas), se había podido mantener al resguardo de los cambios, representando, en palabras de El Correo Vascongado, "un delicioso oasis en desierto revolucionario de España".

Este oasis muy pronto derivó en un desierto contrarrevolucionario al estallar una nueva guerra carlista. Pues bien, a pesar de considerarla consecuencia directa de la revolución y de coincidir en algunos de sus aspectos programáticos, Antonio Trueba no se sumó a esa causa por su rechazo a la vía insurreccional y fidelidad a Isabel II. Apoyó la empresa de Restauración y la figura de Alfonso XII, como la vía más factible para la reconciliación, pero entendida como un simple retorno a la cultura y al modelo politico-social moderado, que tan favorable habia sido para el País Vasco. Pues bien, a la espera de que esta empresa pudiera prosperar, Antonio Trueba reafirmó los pilares maestros que regían su pensamiento y su literatura, "Dios, la patria, la familia y el trabajo", y procedió a adecuarlos a los nuevos tiempos, complementando el universo rural, que siempre le habia definido, con la actividad industrial, que entonces despegaba en Vizcaya.

Sin embargo, paralelamente, y sobre todo a partir de su estancia en Madrid, se tuvo que enfrentar al desarrollo de una opinión liberal que, identificando a los Fueros y a los vascongados con el carlismo y la guerra civil, abogaba por la 
supresión de los regimenes peculiares y la construcción de un auténtico Estado nacional. Pues bien, para intentar contrarrestar este discurso, Antonio Trueba, además de recurrir a los mitos forales tradicionales (vasco-iberismo, independencia originaria, incorporación pactada...), hizo un particular hincapié en aquellos elementos definidores de una nación cultural como el euskera y la cultura tradicional vasca, el ejemplar, virtuoso y religioso pueblo vascongado y la ordenación foral ancestral legitimada por su pasado y por su adaptación a las condiciones particulares de las provincias Vascongadas. Afirmada de esta manera la identidad colectiva vasca, la hacia representar por los que habian sido leales, los que constituían la mayor suma de riqueza, ilustración y sacrificios. Pues bien, detrás de este elitismo conservador, lo que pretendía era que la cuestión foral, al igual que ocurriera en la época isabelina, se dirimiera en ámbito ejecutivo como una reanudación del pacto entre las provincias y la Corona.

En estas mismas ideas incidió Antonio Trueba en las representaciones que le encargaron las Diputaciones "contra la abolición de los Fueros". El eje principal de la argumentación giró en torno a la ley de 25 de octubre de 1839 que, siendo para él y los fueristas confirmatoria de los Fueros como un sistema completo de gobierno, era la expresión del reconocimiento y continuación de ese pacto con la Corona. Este acuerdo no se había roto con la guerra porque nada había tenido que ver con los Fueros, siendo su abolición un castigo injusto y desmesurado para los liberales vascongados y para el conjunto de las poblaciones, que no sólo habían quedado al margen de las rebeliones y transgresiones del orden del resto de la Monarquía, sino que siempre había dado pruebas de un acendrado patriotismo.

Ya antes de que estas exposiciones no prosperan y se aprobara la ley de 21 de julio de 1876, Antonio Trueba de manera un tanto premonitoria habia introducido en su discurso un cierto sesgo desnacionalizador español. Así España o la opinión española no vasca desarrolló un cierto grado de desafección y de opresión hacía las Vascongadas, y éstas, por una parte, empezaron a aparecer como víctimas inocentes e injustas, ya que eran castigadas a pesar de haber sido el principal dique de contención de la revolución. A partir de esta diferente perspectiva el escritor vizcaíno realizaría una relectura de la politica seguida por la Monarquía isabelina con estas provincias que, definida por una sucesión de contrafueros, supondría que al final del reinado "apenas quedara del Código foral más que la portada". Esta visión más distante de la reina de los regímenes forales facilita a Antonio Trueba para, que con la promulgación de esa norma por la Restauración, hacer pasar a la historia a Alfonso XII como el monarca "que derribó el santo árbol simbólico de las libertades vascongadas". En definitiva, se produce un distanciamiento de la Monarquía, que es la antesala de la inhibición del Estado y de la nación española y de la afirmación idea de nacionalidad como identidad colectiva vasca, característica del fuerismo intransigente al que se suma Antonio Trueba.

Fecha de envío / Submission date: 14/08/2020

Fecha de aceptación / Acceptance date: 19/10/2020 